\title{
O KOMUNIKATYWNOŚCI JĘZYKA PRAWNEGO
}

\author{
Robert ZAWLOCKI, Profesor \\ Wydział Prawa i Administracji, Uniwersytet im. A. Mickiewicza \\ al. Niepodległości 53, 61-714 Poznań, Poland \\ zawlocki@amu. edu.pl
}

\begin{abstract}
Abstrakt: Niniejszy artykuł poświęcony został zaprezentowaniu prawa karnego jako celowego tworu językowego o określonych cechach. Omówienia takiego ujęcia Autor dokonuje poprzez odniesienie się do istoty prawa karnego. Następnie, odnotowując fakt, iż język jest środkiem komunikowania się określonych podmiotów, przeprowadza rozważania w zakresie języka adresatów prawa karnego, języka twórców prawa karnego, a na końcu - języka interpretatorów prawa karnego.

Taka płaszczyzna oceny obecnie obowiazującego prawa karnego prowadzi do wniosku, że prawodawca $\mathrm{w}$ znacznym stopniu nie ustanawia norm prawnokarnych $\mathrm{w}$ sposób $\mathrm{w}$ pełni odpowiedzialny, tzn.: świadomy, racjonalny, prosty, zrozumiały i uzasadniony. Język prawa karnego musi zaś wykazywać określone cechy, aby był odpowiednim środkiem realizacji celów prawa karnego. Język prawa karnego pozbawiony tych cech nie tylko pozbawia prawo karne skuteczności, lecz dodatkowo wpływa dysfunkcjonalnie na stosunki społeczne, które ma chronić. Obywatelowi nie można bowiem zarzucić naruszenia obowiazku posłuchu dla normy prawa karnego, gdy obiektywnie norma ta do obywatela nie mogła dotrzeć z uwagi na istotną wadliwość jej nośnika.

W opinii Autora, we współczesnym rodzimym prawie karnym materialnym niemała część przepisów (norm) nie jest określona we właściwym języku prawnym i nie spełnia wymogu komunikatywności, co skłaniać winno do ich pilnego usunięcia lub korekt.
\end{abstract}

\section{COMMUNICATIVE NATURE OF LEGAL LANGUAGE}

Abstract: The paper presents the criminal law as a purposeful linguistic composition with a specific characteristics. The Author elaborates this conceptualization through a reference to the criminal law's essence. Subsequently, bearing in mind the fact that a language is being a communication device, he conducts further analysis concerning the language of the criminal law's addressees, lawmakers and, lastly, interpreters.

The analysis made from the abovementioned assessment perspective leads to a conclusion that the lawmaker, extensively, does not legislate in a fully reasonable manner, i. e.: knowingly, reasonably, simply, understandably and rightfully. The criminal law parlance should be specifically attributed to serve as a measure fulfilling the criminal law's objectives. Otherwise, not only criminal law's effectiveness deteriorates, but it additionally negatively affects social relationships which it should actually protect. A citizen cannot be accused of breaching a duty to comply with a criminal law norm, when the norm objectively could not impact the citizen's behavior, because of a faultiness of its medium. In the Author's opinion, a significant part of current Polish substantial criminal law provisions (norms) are not expressed in an appropriate legal language, being contrary with a prerequisite of communicativeness. Therefore, those provisions should be amended.

Słowa kluczowe: język prawny, cechy języka prawnego, komunikatywnośc 


\section{Wprowadzenie}

1. Język prawa karnego jest środkiem złożonego i wielopłaszczyznowego komunikowania się pomiędzy obywatelami i organami państwa. ${ }^{25}$ Jest on w szczególności nośnikiem informacji dotyczących stosowania odpowiedzialności prawnej o charakterze karnym. Chodzi przy tym o język prawa karnego w sensie ścisłym (język prawny), a nie język o prawie karnym (język prawniczy). Powodem zajęcia się tą problematyką jest przekonanie, iż wskazana komunikacja jest coraz słabsza. Język karno-prawny przestaje spełniać swoją ww. podstawową funkcję, co odpowiednio musi czynić mniej skutecznym samo prawo karne. Prawotwórcy, interpretatorzy prawa, jak i prawo stosujacy, już coraz rzadziej wychodzą z założenia, że prawo karne jest wyłącznie tworem człowieka, o człowieku i dla człowieka. Jednocześnie należy zauważyć, iż przywołane zjawisko pogarszającej się, a w niektórych fragmentach - wręcz zanikającej komunikacji, wciąż pogłębia się, czemu jednocześnie towarzyszy niesłabnące samozadowolenie niemałej części przedstawicieli nauki, którzy ugrzęźli w różnych teoriach, niezrozumiałych już nie tylko dla zwykłego człowieka, lecz również dla specjalistów. Czy rzeczywiście rozumienie powszechnie obowiązującego prawa karnego wymaga powszechnie niezrozumiałych sposobów jego wykładni?

Wyżej przywołana, pierwotna i ogólna funkcja języka prawa karnego sprowadza się do informowania wszystkich jego adresatów o warunkach i sposobie stosowania reakcji karnoprawnej (kary kryminalnej). ${ }^{26}$ Tak ujmowana jego funkcjonalność jest uzależniona od wielu różnych czynników. Celem niniejszego opracowania jest omówienie najważniejszych z nich. Realizacja tego celu sprowadza się do wyjaśnienia następującego problemu badawczego: jakie cechy ma język adresatów i język twórców prawa karnego, jaka zachodzi pomiędzy nimi relacja, jak wplywa ona na znaczenie i rozumienie języka prawa karnego, a ostatecznie - na stosowanie samego prawa karnego?

Powołany cel badawczy będzie realizowany w oparciu o założenie, iż przynajmniej na gruncie prawa karnego - język jest jedynie środkiem realizowania przez człowieka pożądanych przez niego celów, a więc szczególnym sposobem jego samorealizacji. Założenie to prowadzi zaś do głównej myśli tej rozprawy, że człowiek powinien w zakresie prawa karnego posługiwać się językiem (literą prawa) w sposób odpowiedzialny, tzn.: świadomy, racjonalny, prosty, zrozumiały i uzasadniony.

\footnotetext{
${ }^{25}$ Zob. szerzej w: L. Morawski, Główne problemy współczesnej filozofii prawa. Prawo w toku przemian, Warszawa 2005, s. 121 i nast., oraz M. Zirk-Sadowski, Wprowadzenie do filozofii prawa, Warszawa 2011, s. 81 i nast.

Należy przyjąć za T. Nowakiem, że: „Komunikacja to, najogólniej rzecz biorąc, proces porozumiewania się ludzi za pomocą znaków w obrębie pewnej społeczności.” w: Język w świetle nauki, Kraków 2011, s. 321.

26 Tak rozumianą „komunikację" należy odróżnić od komunikacji pojmowanej w ramach tzw. komunikacyjnych teoriach kary, które sprowadzaja sam akt ukarania do swoistego komunikatu wysłanego przez społeczeństwo przede wszystkim sprawcy oraz pokrzywdzonemu. Zob. szerzej w: B. Wojciechowski, Interkulturowe prawo karne. Filozoficzne podstawy karania w wielokulturowych społeczeństwach demokratycznych, Torun 2009, s. 383 i nast.
} 
W przeciwnym razie, to nie człowiek, lecz używany przez niego środek (porozumiewania się), czyli język będzie wyznaczał cele człowieka i decydował o ich osiagnięciu.

Rzecz oczywista, posłużenie się językiem prawa karnego, wymaga wtedy uprzedniego określenia przez człowieka pożądanych przez niego celów. Na omawianej tutaj płaszczyźnie cele te sprowadzają się generalnie do stosowania reakcji karnoprawnej (kary kryminalnej) w sposób optymalny, tzn. maksymalnie realizujący racjonalne i uzasadnione potrzeby ogólnospołeczne, oparte na określonym dla danej grupy społecznej systemie wartości moralno-etycznych. Grupa ta, z uwagi na fakt, iż prawo karne jest zasadniczo prawem karania przez dane państwo, jest społecznością tegoż państwa.

2. Niniejsze opracowanie dotyczy języka prawa karnego Rzeczpospolitej Polskiej, która jest dobrem wszystkich obywateli (art. 1 Konstytucji RP), a Naród ma w niej władzę zwierzchnią (art. 4 ust. 1 Konstytucji RP). Zgodnie z art. 2 Konstytucji RP, Rzeczpospolita Polska jest demokratycznym państwem prawnym, urzeczywistniającym zasady sprawiedliwości społecznej. Oznacza to, że wyżej wskazany optymalny cel karania musi opierać się na zasadach sprawiedliwości społecznej. Należy więc tak posługiwać się językiem prawa karnego, aby urzeczywistniać te zasady. ${ }^{27}$

Wydaje się, że zasadniczo sprzeczne $\mathrm{z}$ tak ujmowanym celem byłoby posługiwanie się językiem prawa karnego w sposób niejednolity. Dlatego też należałoby sformułować w tym miejscu kolejne założenie - o konieczności jednolitego posługiwania się językiem prawa w każdym aspekcie: tworzenia, interpretowania i stosowania prawa karnego. $Z$ tego względu nie wyróżnia się dalej problematyki języka prawa karnego ze względu na kolejne etapy posługiwania się nim.

Cel związany $\mathrm{z}$ państwowym stosowaniem reakcji karnoprawnej (kary kryminalnej) sprawia, że język prawa karnego charakteryzuje się szczególnymi cechami. Ta specyfika pozwala zajmować się nim odrębnie od języków innych gałęzi prawa.

Należy uściślić i podkreślić, że przedmiotem poniższych rozważań jest wyłącznie problematyka języka rodzimego prawa karnego materialnego, które uznać należy za pierwotne dla prawa karnego procesowego i wykonawczego.

Zagadnienie tytułowe może być i faktycznie jest rozumiane rozmaicie. Stan ten jest tyleż oczywisty, co jednocześnie niepokojący, albowiem chodzi przecież o kwestię zasadniczą dla problematyki stosowania przez państwo najcięższych dolegliwości osobistych. Nie kwestionując tego stanu faktycznego, należy jednak, właśnie ze względu na wagę problemu, zgłosić pilną potrzebę konsensusu w tej mierze.

3. Niniejsze opracowanie stanowi skromny wkład do dyskusji na temat języka prawa karnego. Wyraża ono jedynie poglądy jej Autora i między innymi z tego powodu nie zawiera ono przywołania i omówienia wszelkich różnych poglądów. Odrębną kwestią jest fakt, iż rodzima nauka prawa karnego nie poświęciła omawianej tutaj kwestii -

${ }^{27}$ Zob. szerzej np. w: M. Szerer, Kultura i prawo, Warszawa 1981, s. 103 i nast. 
delikatnie rzecz ujmując - zbyt wiele uwagi. ${ }^{28}$ Fakt ten nie budzi jednak zdziwienia, w anglosaskiej kulturze prawnej opartej na konkretnym case, dominuje język mówiony $\mathrm{z}$ jego swobodniejszą konwencją, który stanowi w ten sposób drugorzędny środek rozstrzygania odpowiedzialności karnej; w kontynentalnej kulturze prawa stanowionego język (pisany) odgrywa znacznie ważniejszą rolę, jednakże ma on charakter języka narodowego, przez co - w danym państwie - traktowany jest jako rzecz tyleż naturalna, co bezsporna. Przekonanie takie do tej pory w znacznej mierze było uzasadnione, $\mathrm{z}$ uwagi na mniejszą liczbę norm i ich prostszą treść. Obecnie jednak, w dobie prawa karnego wszechobecnego i niskiej jakości, w pełni aktualne jest pytanie o jego język.

4. Przed przejściem do szczegółowych rozważań, należałoby postawić ogólną diagnozę stanu faktycznego, która w zakresie komunikacji języka prawa karnego, sprowadza się do konstatacji, iż twórcy prawa karnego komunikują się nim z jego adresatami w sposób masowy. Masowa komunikacja językiem prawa karnego wynika nie tylko ze znacznej i wciąż rosnącej liczby przepisów prawa karnego, lecz również ich niskiej jakości, związanej m. in. z kazuistyka. Żyjemy w dobie masowej komunikacji z wykorzystaniem języka prawnego. Jest to poniekąd nie tyle wynikiem, co składnikiem ogólnie rozumianej masowej komunikacji, która cechuje czasy współczesne. Konsekwencją tego stanu rzeczy jest inflacja prawa karnego, która czyni go dysfunkcjonalnym na płaszczyźnie każdej z przypisywanych mu funkcji. Im bowiem więcej prawa karnego, tym gorsza jest jego jakość.

Wydaje się, że zagadnienie języka prawa karnego powinno być omówione poprzez odniesienie się w pierwszej kolejności do istoty prawa karnego, to ona bowiem w sposób oczywisty determinuje jego język. Następnie, odnotowując, iż język jest środkiem komunikowania się określonych podmiotów, należy uwzględnić fakt występowania różnych rodzajów podmiotów używających języka prawa karnego. Oznacza to konieczność przeprowadzenia rozważań w zakresie języka adresatów prawa karnego, języka twórców prawa karnego, a na końcu - języka interpretatorów prawa karnego.

\section{Istota prawa karnego a język prawa karnego}

1. Istotę prawa karnego wyznaczają jego cele i treść. ${ }^{29}$ Cele prawa karnego są zdeterminowane jego filozofią, która znajduje bezpośrednie odzwierciedlenie w przypisywanych mu funkcjach. Na treść prawa karnego składają się obowiązujące normy i zasady, pozwalające rozumieć i stosować normy prawa karnego zgodnie z ich funkcją. Bez względu na określoną szczególną filozofię prawa karnego, ogólnie sprowadza się ono do ustanawiania i stosowania kar za czyny szkodliwe społecznie. Bez względu również na

\footnotetext{
${ }^{28}$ Wydaje się, że omawiana tutaj kwestia najczęściej jest poruszana w związku z tylko jednym aspektem funkcjonowania prawa, tj. z jego wykładnią. Przy tej okazji poruszana jest m.in. problematyka języka prawnego, w tym języka prawnego karnego. Przykładem jest tutaj konferencja zorganizowana na Wydziale Prawa i Administracji UW dnia 27.02.2004 r., pod tytułem: „Wykładnia prawa”.

${ }^{29}$ Zob. szerzej w: A. Marek, Prawo karne, Warszawa 2011, s. 6 i nast.
} 
Robert ZAWŁOCKI, O komunikatywności języka prawnego.

określoną teorię karania kryminalnego (utylitarną lub retrybutywna), główną funkcją kary jest wpierw odstraszanie, a następnie (ewentualnie) - wymierzanie dolegliwości i poprawę przestępcy. Funkcjonowanie prawa karnego, poprzez jego określoną treść, sprowadza się więc do jednego komunikatu: nie popetniaj przestepstw, bo będziesz ukarany, a więc jest to nieopłacalne! Prawo karne może funkcjonować dobrze tylko wtedy, gdy komunikat ten, tak na płaszczyźnie generalnej jak i szczegółowej, jest zrozumiały. Oznacza to, że język prawa karnego musi zrozumiale wyrażać ten komunikat w ogólności i w szczegółach. W przeciwnym razie, wpływa on na prawo dysfunkcjonalnie, i to w sposób bezpośredni i bezwzględny. Warto przy tym zauważyć, że niemal wszystkie teorie prawa karnego opierają się na dorozumianym aksjomacie, że prawo karne jest formułowane w języku właściwym dla jego istoty, tzn.: celów i treści. Tymczasem twierdzenie to jest dyskusyjne i powinno stanowić przedmiot badań i oceny, tak samo jak wszystkie dalsze pozostałe (na nim oparte).

Fenomen przestępstwa zwykło się współcześnie ujmować jako swoisty konflikt społeczny, który państwo rozstrzyga przy zagrożeniu lub użyciu kary kryminalnej. Konflikt ten może być rozwiązywany na różne sposoby, przy czym - jak się wydaje współczesne prawo karne zdaje się ewoluować w kierunku mieszanego modelu, obejmującego tak odpłatę jak i konsensus. Wszystkie strony tego konfliktu powinny go definiować w sposób identyczny i rozwiązywać w oparciu o te same reguły. Właściwy, to znaczy - precyzyjny i zrozumiały język prawa karnego gwarantuje realizację tego postulatu. W przypadku, gdy nie wykazuje on tych cech, rozwiązanie wskazanego konfliktu pozostaje jedynie niezrealizowanym postulatem.

2. Prawo karne jest szczególnym środkiem oddziaływania społecznego. ${ }^{30}$ Nie jest ono celem samym w sobie, lecz instrumentem zabezpieczającym porządek publiczny przy pomocy kary kryminalnej (państwowej). Prawo karne jest stanowione i stosowane po to, aby zapewnić bezpieczeństwo stosunkom społecznym uznanym za pożądane, tzn. wartościowane w danej grupie społecznej pozytywnie. Pożądane stosunki społeczne opierają się na zbiorze podstawowych dóbr społecznych, których naruszenie zakłóca prawidłowe funkcjonowanie i rozwój społeczeństwa. Ogólnospołeczna waga tych dóbr sprawia, iż ich naruszenie staje się karygodne. Cel prawa karnego determinuje jego funkcje.

Prawo karne nie realizuje swojego przywołanego celu samodzielnie. Jest ono bowiem jednym $\mathrm{z}$ wielu, także prawnych, środków oddziaływania społecznego. W związku z tym, cele, funkcje i treść prawa karnego powinny być ujmowane w ścisłym związku z celami, funkcjami i treścią innych środków zabezpieczających pożądane stosunki społeczne. ${ }^{31}$

Prawo karne realizuje swój cel poprzez kryminalizację i penalizację najpoważniejszych patologii społecznych. Obraz patologii społecznych określa kryminologia. Zasady kryminalizacji i penalizacji określa polityka kryminalna, a w szczególności jej zasady. W ten sposób prawo karne zdeterminowane jest

30 Zob. szerzej w: A. Marek, System Prawa Karnego. Tom 1. Zagadnienia ogólne, pod red. A. Marka, Warszawa 2010, s. 2 i nast.

${ }^{31}$ Zob. szerzej np. w: M. Szerer, karanie a humanizm, Warszawa 1964, s. 93 i nast. 
kryminologią i polityką kryminalną. Oznacza to, iż jakikolwiek akt kryminalizacji i penalizacji powinien być poparty rzetelną analizą kryminologiczną i przeprowadzony zgodnie z przyjętymi zasadami polityki kryminalnej. Państwo (rząd) nie może posługiwać się prawem karnym w inny sposób, albowiem wtedy czyni to nieracjonalnie. Również interpretacja i stosowanie prawa karnego powinny uwzględniać przesłanki i zasady jego stanowienia, w przeciwnym razie będą abstrahowały od jego podstaw.

Cel prawa karnego jest w pełni zorientowany społecznie. W demokratycznym państwie prawnym oznacza to, iż jest on zorientowany antropologicznie. To znaczy, że człowiek, a w szczególności jego dobra, opierające się na przyjętym systemie wartości etycznych, są celem prawa karnego. Jeżeli człowiek jest celem prawa karnego, to powinno ono mieć w każdym aspekcie wymiar humanistyczny. Stanowienie, interpretacja i stosowanie prawa karnego sprzecznie $\mathrm{z}$ tą zasadą stanowi pogwałcenie jego celu (współwyznaczającego jego istotę), a zatem stanowi naruszenie podstawowej idei prawa karnego. Wtedy prawo karne traci swój pierwotny sens.

Prawo karne realizuje swoje cele przy użyciu instrumentów w postaci kar kryminalnych. Z tego względu, cele prawa karnego determinuja cele kary (karania). Jednocześnie jednak cele kary są ograniczone jej treścią, która sprowadza się do dolegliwości osobistej wymierzanej przez państwo. Cel prawa karnego, w postaci zabezpieczenia porządku publicznego, jest więc tutaj realizowany poprzez specyficzny środek w postaci określonej dolegliwości. W tym kontekście celem kary kryminalnej jest przede wszystkim odstraszanie od zachowań stanowiących zakazane naruszenie porządku społecznego.

3. Funkcje prawa karnego są emanacją funkcji (celów) państwa, określonych w ustawie naczelnej. Język prawa karnego ma urzeczywistniać te cele, co jest ważne dla sposobu jego tworzenia, interpretowania i stosowania. ${ }^{32} \mathrm{~W}$ demokratycznym państwie prawnym podstawowym punktem odniesienia jest człowiek (obywatel). Społeczny cel prawa karnego również określa jego humanistyczne i humanitarne funkcje, a właściwie takie ich rozumienie.

Funkcje prawa karnego to formułowane przez prawodawcę i realizowane przez organy stosujące prawo karne jego naczelne zadania, których istota sprowadza się do odpowiedzi na pytanie: po co tworzy się i stosuje prawo karne? W tym kontekście, funkcje prawa karnego sprowadzają się do jego generalnych celów. Konieczne jest podkreślenie dynamicznego charakteru funkcji prawa karnego. Związane jest to z istniejącymi rozbieżnościami pomiędzy ogólnie (teoretycznie) formułowanymi celami prawa karnego, a celami formułowanymi przez prawodawcę ad hoc (co związane jest przede wszystkim z realizacją bieżącej polityki przez dany rząd). Rozbieżności zachodzą również w rzeczywistej funkcjonalności prawa karnego, która jest zmienna w zależności od określonych okoliczności (czasu, miejsca, rodzaju przestępstw lub kar, rodzaju sprawców lub pokrzywdzonych itp. itd.).

Celowy charakter prawa karnego istotnie determinuje pojmowanie jego języka, który również należy traktować celowo. Zabieg ten przejawia się trojako. W pierwszej

\footnotetext{
${ }^{32}$ Zob. szerzej w: Wł. Wróbel, A. Zoll, Polskie prawo karne. Część ogólna, Kraków 2010, s. 39 i nast. 
Robert ZAWŁOCKI, O komunikatywności języka prawnego.

kolejności prawotwórca powinien tworzyć przepisy prawa karnego w ścisłym nawiązaniu do racji, dla których są ustanawiane. Nawiązanie to odnosi się tak do formy, treści, jak i systematyki przepisów karnych. Prawidłowa realizacja tego zabiegu powinna prowadzić do ustanowienia przepisu karnego, którego cel (funkcja) nie może budzić wątpliwości. O ile bowiem język może i jest rozumiany różnie, to cel wyrażeń języka prawnego nie może budzić jakichkolwiek waţliwości. Oznacza to, że przepis prawa karnego, który ze względu na swoją treść, formę lub klasyfikację - wywołuje uzasadnione wątpliwości co do swojej funkcji, jest przepisem sprzecznym $\mathrm{z}$ funkcją prawa karnego, a zatem przepisem nie tylko praktycznie dysfunkcjonalnym, lecz również teoretycznie sprzecznym z podstawową normą kompetencyjną stanowienia prawa karnego, zawarta w Konstytucji RP, opartą na zasadzie demokratycznego państwa prawnego.

W drugiej kolejności, celowy charakter prawa karnego sprawia, że interpretacja karnistyczna powinna zawsze odwoływać się do wykładni celowościowej, przyjmując, że określony przepis prawa karnego został stworzony dla osiagnięcia danego konkretnego celu. Na tej podstawie można sformułować twierdzenie, że interpretacja karnistyczna nie może opierać się wyłącznie na wykładni językowej. W szczególności, ograniczenie się do takiej wykładni w żadnym wypadku nie może uzasadniać przekonanie (uznanie) interpretatora, że dany przepis jest językowo jasny. Jeżeli bowiem tak jest, to może to oznaczać tylko tyle, że jest on jasny językowo w kontekście jego celów. Zaniechanie uwzględnienia racji funkcjonalnych i ograniczenie się wyłącznie do znaczenia językowego stanowi w związku $\mathrm{z}$ tym naruszenie prawa karnego, sprowadzające się do jego rozumienia niezgodnie $\mathrm{z}$ jego immanentnie dynamiczną istota.

Celowy charakter prawa karnego przejawia się w końcu w określonym stosowaniu prawa karnego. Należy je bowiem stosować zgodnie z jego przeznaczeniem (funkcja).

4. Idea państwa demokratycznego polega $\mathrm{m}$. in. na tym, że interesy społeczeństwa i państwa są tożsame. Ponadto, są one określone, obiektywne i istotne, co znowu należy związać z naczelną konstytucyjną zasadą demokratycznego państwa prawnego. Interesy te są określone, czyli wybrane spośród ogółu różnych interesów. Są one obiektywne, ponieważ podstawą ich wyróżnienia są rzeczywiste interesy ogółu, a nie partykularne interesy określonej grupy lub opcji społecznej. I w końcu, są one istotne, albowiem odnoszą się do najważniejszych interesów społeczno-państwowych.

Interesy, o których mowa powyżej, są identyfikowane jako dobra społeczne, zasługujące na karnoprawną ochronę i podlegające takiej ochronie, co czyni je dobrami prawnymi (karnoprawnymi). $\mathrm{Na}$ tej podstawie, nauka prawa karnego wyróżnia podstawową funkcję ochronną prawa karnego, która sprowadza się do ochrony dóbr społecznych.

Wskazana ochrona odbywa się przy użyciu specyficznych środków oddziaływania społeczno-państwowego, tj. środków karnoprawnych, które są środkami najcięższego przymusu państwowego. Oddziaływanie przy użyciu takich środków istotnie determinuje funkcjonalność prawa karnego. W szczególności, funkcjonalność ta jest znacznie ograniczona. Oddziaływanie środkami skrajnie negatywnymi jest bowiem co do zasady ograniczone $\mathrm{w}$ porównaniu $\mathrm{z}$ obojętnym oddziaływaniem regulacyjnym 
(pozbawionym sankcji lub $\mathrm{z}$ sankcją łagodna) oraz oddziaływaniem pozytywnym (związanym z nagradzaniem).

Okoliczność ta znacznie ogranicza obiektywną funkcjonalność prawa karnego i powinna ograniczać zakres stanowienia (stanowionego) prawa karnego, wyłącznie do takich interesów, które spełniają ww. cechy.

5. Język stanowi również specyficzny środek oddziaływania prawa karnego. Jest on w szczególności podstawowym środkiem realizacji jego funkcji ochronnej. W tym znaczeniu, język prawa karnego chroni dobra społeczne. Czyni to w dwojaki sposób, poprzez stanowienie i obowiązywanie, a zatem poprzez samą swoją treść (normy), jak również poprzez stosowanie (realizację norm). Wskazana karnoprawna funkcjonalność języka prawa karnego jest nierozdzielna i przenika się nawzajem. W szczególności nie można jednoznacznie ustalić, czy prawo karne chroni dobra społeczne bardziej poprzez jego obowiązywanie, czy stosowanie. Niewatpliwie intencją prawotwórcy jest jak najbardziej rozległe oddziaływanie prawa karnego właśnie w tej pierwszej statycznej sferze. Prawo karne, z powodów czysto zdroworozsądkowych, opiera się na zasadzie ultima ratio nie tylko przy stanowieniu, lecz również stosowaniu. Stosowanie prawa karnego sprowadza się $\mathrm{w}$ tym znaczeniu do niewłaściwego lub niepełnego zafunkcjonowania prawa karnego w ujęciu statycznym, jako obowiązującego systemu przepisów prawa, wyrażających zakazy określonego zachowania się pod groźbą kary kryminalnej.

Powołana intencja prawotwórcy zasługuje bez wątpienia na pełną aprobatę. Można nawet pokusić się o hipotezę, że sfera statyczna prawa karnego realizuje przypisaną jemu podstawową funkcję ochronną w znacznej (przeważającej) mierze. Należy jednak zauważyć, że jej realizacja wymaga języka o określonych cechach. Związane są one z przekonaniem, że prawo karne optymalnie funkcjonuje w sferze statycznej tylko wtedy, gdy dociera do wszystkich adresatów i jest ono dla tych adresatów zrozumiałe nie tylko ściśle językowo (formalnie), lecz również aksjologicznie (materialnie). ${ }^{33}$ Stawia to przed prawodawcą wymóg stanowienia prawa karnego w języku prostym (powszechnie zrozumiałym) i odwołującym się do powszechnie akceptowalnego i powszechnie zrozumiałego systemu wartości społecznych. Odstępstwo od tych wymogów prowadzi bezpośrednio do dysfunkcjonalności prawa karnego. Na marginesie należy odnotować, że prowadzi ono również do zwiększonej skali stosowania prawa karnego. Można $\mathrm{z}$ tego wysnuć wniosek, że zwiększona liczba stwierdzonych przestępstw wcale nie musi wynikać ze zwiększonej liczby popełnionych przestępstw, lecz z niewłaściwego języka prawa karnego odnoszącego się do tych przestępstw.

Statyczna funkcja prawa karnego sprawia, że to język chroni dobra społeczne. Jest to przy tym język represji. Jego istota jest groźba (wymierzenia dolegliwości w postaci kary kryminalnej). Język prawa karnego jest więc językiem groźby. Aby taki

\footnotetext{
33 Interesującą i pogłębioną analizę (krytykę) komunikowania się w zakresie prawa w tylko w oparciu o aspekt formalny przeprowadził M. Matczak w: Summa Iniura. O błędzie formalizmu w stosowaniu prawa, Warszawa 2007.
} 
Robert ZAWŁOCKI, O komunikatywności języka prawnego.

język był skuteczny (funkcjonalny), konieczne jest komunikowania się za jego pomoca przy użyciu wyrażeń prostych i zwięzłych. Oznacza to, że jednostki redakcyjne przepisów karnych powinny być maksymalnie krótkie. Dyspozycje przepisów karnych, określających dane przestępstwo, powinny być więc syntetyczne, a nie kazuistyczne. Uwaga ta odnosi się również do sankcji karnych.

Jednocześnie ważne jest wskazanie, że karnoprawna ochrona dobra prawnego polega na kryminalizacji nie każdego naruszenia tego dobra w każdych okolicznościach, lecz ściśle określonego sposobu jego naruszenia. Przepis prawa karnego wyraża ten fakt. W warstwie językowej skutkuje to tym, iż dyspozycja przepisu karnego powinna maksymalnie precyzyjnie określać wszystkie istotne cechy danego typu czynu zabronionego, a w szczególności jego podmiot oraz stronę przedmiotową i podmiotową karalnego zachowania tego podmiotu. Znamiona ustawowe typu czynu zabronionego pod groźbą kary są więc w pierwszej kolejności wyrazem funkcji ochronnej przepisu, który ten czyn określa.

6. Przepis karny językowo jasny jest dzięki temu zrozumiały, co stanowi racjonalny sposób karnoprawnej ochrony. Przepis jest zrozumiały wtedy, gdy jest formalnie (językowo) zrozumiały oraz zrozumiały materialnie (aksjologicznie), co oznacza, że jego język odpowiada racjonalnie jego celowi. Należy przy tym odróżnić potencjalną obiektywną zrozumiałość przepisu od jego faktycznego subiektywnego zrozumienia. Prima facie, ta druga sfera funkcjonowania (odbioru) przepisu karnego wydaje się być $\mathrm{z}$ punktu widzenia funkcjonowania prawa karnego obojętna. Powstaje jednak istotna wątpliwość przy odwołaniu się do przykładu, gdy dany przepis jest ,językowo" zrozumiały, a w rzeczywistości wszyscy jego adresaci go nie rozumieją lub rozumieja inaczej. Brak zrozumienia może tutaj odnosić się do ww. warstwy formalnej lub materialnej. Wtedy niewątpliwie przepis nie może być praktycznie funkcjonalny. Wskazana wątpliwość jest o tyle niepokojąca, iż wbrew pozorom wcale nie musi dotyczyć przykładu tyleż skrajnego, co teoretycznego. Można bowiem uznać, że taka sytuacja jest właściwie typowa.

Wydaje się, że przywołany przypadek może mieć miejsce przede wszystkim wtedy, gdy prawotwórca nie tylko używa niewłaściwego języka do wyrażenia swojego właściwego celu, lecz przede wszystkim niewłaściwie wyznacza swój cel. Może to odbywać się poprzez brak wskazania celu lub wskazanie go w sposób niejasny (np. pozorny, bo lakoniczny). Sytuacja taka w dobie współczesnego karnoprawnego prawotwórstwa jest niestety powszechna. Wskazany problem można usunąć wyłącznie poprzez opatrzenie projektów ustaw zawierających przepisy karne wyczerpującym i racjonalnym wyjaśnieniem ich ratio legis (przesłankami wprowadzenia przepisu ustawy). Na marginesie należy wskazać, że realizacja tego postulaty nie tylko uczyniłaby znaczną część prawa karnego zrozumiała, lecz również i zrozumianą.

Powyższe rozważania prowadzą do wniosku, że pomiędzy funkcjonalnością (skutecznościa) przepisu karnego a jego zrozumiałością i zrozumieniem zachodzi ścisły związek. W szczególności, zrozumiałość i zrozumienie stanowi konieczną przesłankę właściwego funkcjonowania przepisu. Warunkiem zaś jego zrozumiałości i zrozumienia jest właściwie uzasadnienie jego ratio legis. W ten sposób racjonalne i wyczerpujące 
uzasadnienie każdego przepisu karnego jawi się jako element co najmniej tak istotny, jak sama jego treść. ${ }^{34}$

7. Perswazyjny charakter takiego języka w znacznej mierze opiera się na komunikacie o treści grożącej sankcji karnej. Wydaje się, że w tym zakresie należałoby odwoływać się tylko do jednej i najsurowszej z grożących kar. Oznacza to, że odwołanie się do zagrożenia o charakterze alternatywnym nie jest rozwiązaniem pożądanym. Możliwość stosowania łagodniejszych kar jest bowiem rozwiązaniem związanym z dynamicznym stosowaniem prawa karnego, a zatem skierowanym do organów je stosujących. Jednocześnie należy wskazać, że odwołanie się do najsurowszej kary nie może być relatywizowane poprzez jej szczegółową gradację. Kara najsurowsza jest taka w odbiorze tylko wtedy, gdy jej rodzajowa istota nie jest określona przy odwołaniu się do niskiego progu (maksymalnego zagrożenia o łagodnym charakterze).

Zagrożenie karne jest komunikatywne i w ten sposób funkcjonalne wtedy, gdy jest określane przy użyciu jak najmniejszej liczby progów. Wydaje się, że każdy z rodzajów kar kryminalnych powinien być określany poprzez wskazanie progu (limitu) maksymalnego, średniego i niskiego, co daje liczbę trzech rodzajów sankcji karnej dla każdego rodzaju kary.

Stopień maksymalnego zagrożenia karnoprawnego odpowiada stopniowi maksymalnego niebezpieczeństwa społecznego dla danego typu czynu zabronionego. Wyznaczenie maksymalnej karygodności jest wynikiem przeprowadzonej przez prawodawcę oceny kryminologicznej i polityczno-kryminalnej danego typu czynu zabronionego (przestępstwa). Istota społecznego niebezpieczeństwa nie pozwala posługiwać się szczegółową gradacją. Także w tym zakresie prawotwórca może odwoływać się co najwyżej do konwencjonalnego progu wysokiego, średniego i niskiego. Okoliczność ta stanowi więc dodatkowe istotne wsparcie dla wyżej sformułowanego postulatu posługiwania się trzema poziomami maksymalnej karygodności przy danym rodzaju kary kryminalnej.

8. W nauce prawa karnego wyróżnia się ponadto jego funkcję regulacyjną, gwarancyjną i kompensacyjna. Mają one jednak charakter drugorzędny, a w szczególności wtórny do podstawowej funkcji ochronnej. Jest bowiem oczywiste, że ochrona dóbr społecznych przy użyciu kar kryminalnych pośrednio reguluje stosunki społeczne, poprzez ich rzeczywiste kształtowanie. Należy przy tym odróżnić kształtowanie pożądane (brak zachowań karygodnych) od rzeczywistego, nieraz wręcz dysfunkcjonalnego. Jeśli prawo karne pośrednio ma regulować stosunki społeczne, to jego język powinien nawiązywać wprost do języka, którym posługują się podmioty tych stosunków. Punktem wyjścia jest więc tutaj język potoczny. Język specjalistyczny jest i może być uzasadniony wyłącznie szczególną (,specjalistyczną) funkcją danego przepisu karnego, a zatem „specjalistycznym” charakterem dobra społecznego, podlegającego karnoprawnej ochronie. Dobro takie musi jednak odnosić się, zgodnie z powyższymi rozważaniami, do interesu społeczno-

\footnotetext{
${ }^{34}$ W tym kontekście krytycznie należy ocenić wręcz lakoniczne uzasadnienie do rządowego projektu obecnie obowiązującego Kodeksu karnego, jak również lakoniczne uzasadnienia niemal wszystkich projektów ustaw wprowadzających nowe przepisy karne (przestępstwa).
} 
Robert ZAWŁOCKI, O komunikatywności języka prawnego.

państwowego. Jednakże interes tego rodzaju ma charakter „specjalistyczny” tylko w szczególnych przypadkach. $\mathrm{Na}$ tej podstawie należy sformułować wniosek, że język specjalistyczny w prawie karnym też powinien być używany w wyjątkowych przypadkach.

W związku z powyższym należy odnotować, że rozróżnienie na język potoczny i specjalistyczny nie jest zupełne. Można bowiem wyróżnić język quasi-specjalistyczny, tj. takie, który potoczne zjawiska określa pojęciami spoza mowy potocznej, np. język urzędowy lub naukowy. Używanie takiego języka nie jest więc związane $\mathrm{z}$ charakterem opisywanego zjawiska, lecz szczególnym statusem prawotwórcy (osób projektujących przepisy karne). Wyżej przedstawione rozważania prowadzą do wniosku, że używania takiego języka w prawie karnym prowadzi bezpośrednio do jego dysfunkcjonalności.

Gwarancyjna funkcja prawa karnego jest również pochodną funkcji ochronnej. Powiązanie tych funkcji sprowadza się do stwierdzenia, że karnoprawna ochrona musi być realizowana w taki sposób, aby nie naruszać w sposób nieuzasadniony praw człowieka i obywatela. W ten sposób funkcja gwarancyjna limituje funkcję ochronną prawa karnego. Wskazana limitacja odnosi się również wprost do języka prawa karnego. Musi on bowiem być formułowany i interpretowany w taki sposób, aby realizował wyłącznie ściśle określoną zasadną funkcję (cel) danego przepisu karnego. W powołanym rozumieniu, karnoprawna ochrona dobra społecznego uzasadnia ograniczenie lub wyłączenie określonych praw człowieka i obywatela, ale tylko w zakresie wynikającym ze ściśle określonej ratio legis danego przepisu. W demokratycznym państwie prawnym funkcja gwarancyjna jest więc immanentnym uzupełnieniem funkcji ochronnej. Ta ostatnia sprawia, że przepisy karne powinny być określone maksymalnie precyzyjnie, tak, aby wyrażony językowo zakres i treść penalizacji nie był bezsporny, a przy tym odzwierciedlał cel danego przepisu karnego.

Pomiędzy funkcją ochronną a funkcja gwarancyjną zachodzi szczególnego rodzaju napięcie. Na płaszczyźnie językowej, ujmując rzecz w uproszczeniu, napięcie to przejawia się tym, że cel przepisu skłania do jego stanowienia i interpretacji z tendencją rozszerzająca, gdy tymczasem zagwarantowanie praw człowieka i obywatela skłania $\mathrm{w}$ tej mierze do tendencji przeciwnej. W skrajnym ujęciu, i w dalszym ciagu upraszczając, racje funkcji gwarancyjnej redukują znaczenie wykładni funkcjonalnej (celowościowej) na rzecz wykładni językowej. Przejawem opisywanego problemu byłaby konstrukcja syntetyczna dyspozycji przepisu karnego uzasadniona funkcja przepisu i konstrukcja kazuistyczna uzasadniona realizacją gwarancji praw człowieka i obywatela. Wskazane napięcie przenosi się zatem również na płaszczyznę języka prawa karnego.

Zaproponowanie formuły godzącej wskazane przeciwności jest niezwykle trudne, ponieważ zjawisko to jest bardzo złożone. Wydaje się, że należy w pierwszej kolejności zauważyć, że w omawianym zakresie gwarancja ma charakter wtórny do celu. Oznacza to, że jej racje są doniosłe tylko wtedy, gdy cel ten jest niewłaściwy albo dyskusyjny. Dotyczy to sytuacji, w której cel nie został prawidłowo określony lub realizacja celu określonego sprawia, że środek wyrażający ten cel, czyli określone wyrażenia języka (przepisu) prawa karnego jest niejasny. W takiej, i tylko w takiej sytuacji można skutecznie użyć racji wynikających z funkcji gwarancyjnej prawa karnego. Przywołany zabieg należy stosować nie tylko przy interpretacji karnistycznej, lecz również przy 
stanowieniu i stosowaniu prawa. Wtedy każdą wątpliwość związaną z realizacją ochronnego celu prawa karnego należy rozstrzygać na rzecz obywatela, a w szczególności jego uprawnień. Konstatacja taka pozwala sformułować postulat syntetycznego formułowania przepisów karnych.

$\mathrm{Na}$ koniec tego wątku należy wskazać, że przywołany przy okazji omawiania funkcji ochronnej postulat formułowania przepisów karnych w sposób zwięzły i jasny w pełni koresponduje $\mathrm{z}$ racjami funkcji gwarancyjnej. Prosty i jasny przepis jest dla jego adresata zrozumiały. Ta cecha przepisu karnego stanowi istotny element poszanowania praw osób, które miałby ponosić odpowiedzialność karnoprawną na jego podstawie.

Wśród funkcji prawa karnego wyróżnia się jeszcze funkcje: sprawiedliwościowa i kompensacyjną. Wydaje się, że ich istota jest jednakowa. Prawo karne sprowadza się w tym kontekście do właściwej reakcji państwa na zło (przestępstwo) wyrządzone na jego terytorium. Karanie stanowi tutaj społeczny akt wymierzenia sprawiedliwości. Akt ten w szczególności sprowadza się w określonych przypadkach (wyrządzenia zła majątkowego) do majątkowego zadośćuczynienia (kompensacji), stanowiącego element odpowiedzialności karnoprawnej. Kompensacyjna funkcja karania odgrywa więc tutaj drugorzędną rolę. ${ }^{35}$

9. Prawo karne jest po to, aby wymierzać społeczną sprawiedliwość. Prawo karne nie pozwalające lub utrudniające wydawanie decyzji niesprawiedliwych jest dysfunkcjonalne. Język prawa karnego musi uwzględniać te okoliczności. W związku z tym należy wskazać, że społeczeństwo pojmuje sprawiedliwość odwołując się przede wszystkim do reguł niepisanych. Społecznej formuły sprawiedliwości nie można wyrazić wprost językiem. Ewentualny przepis wskazujący, że prawo karne ma być sprawiedliwe $\mathrm{w}$ istocie nie wprowadzałby do systemu prawa nic nowego i dodatkowego. Wyrażenia (przepisy) prawa karnego stanowią wtedy tylko i aż pośrednie środki jej realizacji. Element sprawiedliwości prawa karnego musi być obecny w obowiązujących przepisach, a najlepszą formułą jego wyrażenia są określone klauzule generalne, których istota pozwala go uwzględnić. ${ }^{36}$

Sprawiedliwość prawa karnego związana jest z tym, za co i, jak oraz jaka prawotwórca grozi karą kryminalną. Za pośrednictwem tych elementów realizowana jest karnoprawnie sprawiedliwość społeczna. Język prawa karnego musi być w tym sensie sprawiedliwy, tak w warstwie formalnej, jak i aksjologicznej. Realizacja tego zadania jest niezwykle trudna nie tylko dlatego, że chodzi tutaj o pośrednie wysłowienie określonego poczucia, lecz również dlatego, że społeczna formuła sprawiedliwości związana jest z poczuciem konieczności karalności i karania rozległego i surowego. Należy wobec tego odwołać się do racji funkcji ochronnej i jej cech, jak również racji funkcji gwarancyjnej, które w omawianym tutaj sensie łącznie limitowałyby funkcję sprawiedliwościową.

35 Trafny jest tutaj argument wywodzący się z ekonomicznej analizy prawa karnego, a sprowadzający się do przewrotnego pytania: jak dużo pieniędzy musisz otrzymać, żeby się zgodzić na to, aby ktoś napadł ciebie młotkiem? Por. R. Cooter, T. Ulen, Ekonomiczna analiza prawa, Warszawa 2011 (red. nauk.: J. Bełdowski, K. Metelska-Szaniawska), s. 597.

${ }^{36}$ Por. R. Zawłocki, Pojęcie i funkcje społecznej szkodliwości czynu zabronionego, Warszawa 2007, s. 253 i nast. 
Robert ZAWŁOCKI, O komunikatywności języka prawnego.

10. Przepisy prawa karnego materialnego określają warunki pociagnięcia do odpowiedzialności karnej. Realizuja one funkcje prawa karnego, zgodnie $\mathrm{z}$ jego zasadami, i stanowią nośniki norm prawa karnego materialnego, tj. normy sankcjonowanej i sankcjonującej. W sekwencji fenomenów prawnokarnych: funkcje - zasady - przepisy - normy, to właśnie przepisy są bezpośrednim przedmiotem języka prawa karnego. Funkcje, zasady i normy wyrażone są w nim zatem tylko pośrednio. Jednocześnie jednak są one immanentnym elementem tego języka. Oznacza to nie tylko, że są one z języka prawa karnego nieusuwalne, lecz przede wszystkim to, że są one w tym języku zawsze obecne. Okoliczność ta nadaje przepisem prawa szczególnego pozajęzykowego znaczenia. Dodać należy, że uwaga ta dotyczy zarówno stanowienia, jak i interpretacji oraz stosowania prawa karnego.

\section{Język adresatów prawa karnego}

1. Nieodwracalnie do przeszłości należą proste stosunki społeczne, w których funkcjonuja proste zakazy i - odpowiednio - prosty język zakazów sankcjonowanych kara. Współcześnie Mojżesz musiałby, zamiast swoich kamiennych dwóch tablic, przekazać ludziom online terabajty skomplikowanych danych. Obecne stosunki społeczne są nader złożone, w związku z czym odpowiednio złożone są normy postępowania i język. Ludzkość nieodwracalnie wkroczyła w erę masowej komunikacji, która obejmuje nie tylko kwestie życia codziennego, lecz również normy postępowania. W związku z tym język prawa złożony być musi i z pewnością w przyszłości będzie coraz bardziej złożony. Rzecz jednak w tym, aby stanowił on naturalny element swoich czasów (stosowanego sposobu komunikacji) i był dzięki temu komunikatywny.

Język prawa karnego jest językiem jego adresatów i twórców. Prawotwórcy określają normy adresując je do określonego kręgu osób, formułując je w języku adresatów. Nie jest to kwestią określonej konwencji lub dowolnego wyboru, lecz bezwzględnej konieczności. Prawo karne może bowiem realizować swoje cele tylko wtedy, gdy jest stosowane przez jego adresatów, którzy znowu mogą to czynić wyłącznie wtedy, gdy są $w$ stanie zrozumieć treść normy. Prawo karne musi więc być komunikowane w języku adresata.

Język adresatów prawa karnego wykazuje w związku z tym charakter pierwotny do języka twórców prawa karnego. Język prawa karnego jest oparty na języku jego adresatów. Ten pierwszy jest szczególnym rodzajem drugiego. Okoliczność ta sprawia, że język prawa karnego musi opierać się na regułach znaczeniowych języka używanego przez adresatów prawa karnego. Naruszenie tego obowiązku jest praktycznie równoznaczne $\mathrm{z}$ komunikowaniem się autora informacji $\mathrm{z}$ jej adresatem $\mathrm{w}$ języku dla tego ostatniego niezrozumiałym, czyli obcym. Złe komunikowanie się w omawianym względzie zdaje się być z punktu widzenia celów prawa karnego nawet bardziej szkodliwe niż brak jakiejkolwiek komunikacji.

2. W naukach społecznych przyjmuje się bezspornie, iż istotą określonego społeczeństwa, a ściślej - rdzeniem struktury społecznej jest jej normatywny charakter. Istnienie i charakter społeczeństwa wyznaczane jest przez reguły zachowania. W tym 
sensie porządek społeczny dla socjologów jest synonimem jego normatywnego ładu. ${ }^{37}$ Przejawem tego jest określona kultura danego społeczeństwa, której podstawą są - jak wskazuje A. Giddens - ,idee określające, co uchodzi za ważne, wartościowe i pożądane”. ${ }^{38}$ Porządek danego społeczeństwa wyznacza zatem przede wszystkim określony system norm o charakterze aksjologicznym. Podstawami tego aksjologicznego porządku społecznego sa uniwersalne wartości etyczne i estetyczne, które w preambule do Konstytucji RP określono jako: prawda, sprawiedliwość, dobro i piękno. Można by rzec, iż społeczeństwo i jego normy to dwa nierozłączne elementy. Do tego zespołu elementów dochodzi trzeci, który również jest z nimi nierozerwalny - język. Spełnia on w społeczeństwie wiele istotnych funkcji wyznaczających świadomość społeczną, w tym m. in. - komunikacji międzyludzkiej (społecznej). ${ }^{39}$ Język stanowi swoisty nośnik norm społecznych, stając się tym samym podstawą istnienia społeczeństwa i ważnym wyznacznikiem jego normatywnej tożsamości. Oznacza to, że w społeczeństwie funkcjonuje określony język norm społecznych. Adresaci języka prawa karnego nie tylko mają system norm społecznych, lecz również język ich komunikowania. Jest to sytuacja stanowiąca istotny punkt wyjścia w procesie tworzenia prawa karnego.

3. Prawo karne jest prawem karania przez państwo, jest więc prawem państwowym (danego państwa). Prawo karne ma więc zasadniczo charakter państwowy („,narodowy”), a zatem język prawa karnego musi mieć charakter narodowy. Narodowość języka prawa karnego jest jego immanentną cecha, należy do jego istoty i pozwala zrealizować jego cele. W przypadku, gdy język prawa karnego jest obcy w stosunku do języka narodowego, zanika $\mathrm{W}$ tym zakresie komunikacja pomiędzy państwem a jego obywatelami.

Powyższa uwaga w pełni odnosi się również do norm ustanawianych przez dane państwo w następstwie uczestniczenia przez nie w określonej organizacji międzynarodowej. Międzynarodowe prawo karne stosowane przez to państwo powinno być wyrażane w języku tegoż państwa (np. w postaci oficjalnych tłumaczeń).

Całkowicie odrębną kwestią jest międzynarodowe prawo karne stosowane nie przez dane państwo, lecz międzynarodowe trybunały karne. Państwa ustanawiające takie trybunały przyjmują odrębne zasady odpowiedzialności oparte na słuszności i sprawiedliwości. Takie prawo karania nie jest prawem karnym danego państwa. Takie prawo karania oparte jest na najprostszych i podstawowych normach i skierowane jest do wszystkich. W tej sytuacji wymóg komunikacji prawa jest znacznie złagodzony. ${ }^{40} \mathrm{~W}$ rezultacie prawo takie może być wyrażone w dowolnym języku, nawet nie stosowanym przez żadne państwo (np. w łacinie).

Narodowy charakter języka nie sprowadza się wyłącznie do formalnego komunikowania się w nim narodu społeczeństwa. Język narodowy stanowi również nośnik samej indywidualności narodu, stanowi wyraz jego duchowej i intelektualnej

\footnotetext{
${ }^{37}$ Por. P. Sztompka, Socjologia zmian społecznych, Kraków 2005, s. 234.

${ }^{38}$ A. Giddens, Socjologia, Warszawa 2007 (tłum. A. Sulżycka), s. 45.

${ }^{39}$ Por. P. Sztompka, Socjologia. Analiza społeczeństwa, Kraków 2009, s. 288-292.

${ }^{40}$ Wniosek taki może być uznany za kolejny element koncepcji prawa wroga (Jakobs), lecz należy zauważyć, iż nie wychodzi on z założenia, iż wrogowi systemu należy się mniej, lecz nie należy się to samo; nie z powodu tego, iż jest on wrogiem systemu, lecz tego, iż system go nie obejmuje.
} 
tożsamości. ${ }^{41} \mathrm{Na}$ treść języka narodowego składają się więc nie tylko reguły wyznaczające jego gramatyczno-logiczną zawartość, lecz również właściwe dla danego społeczeństwa reguły, które składają się również na intuicję, tak ważnego składnika rozumienia języka narodowego. ${ }^{42}$

Lingua franca criminalis (wspólny język prawa karnego) właściwy dla społeczności ponadnarodowej, czy nawet całego świata, teoretycznie jest możliwy. Tyle tylko, że wymagałoby to jednego powszechnego języka, który znowu powinien opierać się na wspólnocie aksjologicznej i kulturowej.

4. Język adresatów zakazów karnoprawnych, czyli członków społeczeństwa nie jest prosty i jednolity. Wzajemne komunikowanie się ludzi staje się coraz bardziej intensywne nie tylko ilościowo, lecz również jakościowo. W używanym języku należy wyróżnić co najmniej język potoczny oraz język specjalistyczny, a właściwie mnogość ich rodzajów. Język społeczeństwa właściwie już w każdym rodzaju jest wykorzystywany w języku prawa karnego. Wyjątkiem jest tutaj język żargonowy, którego prawo karne unika ze względu na niestałość i ograniczony zasięg społeczny. W ramach języka potocznego funkcjonuje ugruntowana już warstwa pojęć, które w społeczeństwie używane są dla określenia kwestii związanych z istotą prawa karnego.

Należą do nich przede wszystkim takie pojęcia, jak: „sprawiedliwość”, „wina”, „karygodność”, „przestępstwo”, „odpowiedzialność”. Ich społeczne (potoczne) znaczenia są różne, jednak używają ich wszyscy i to na użytek spraw codziennych. Członkowie społeczeństwa komunikują się pomiędzy sobą również w warstwie norm postępowania. Społeczeństwo ma swoje system norm oceny dobra i zła, a ponadto posługuje się w sposób ugruntowany i jasny takimi pojęciami jak np. „sprawiedliwość” i „wina”. Można wskazywać na istnienie swoistej ogólnospołecznej konwencji komunikowania się w zakresie rozróżniania dobra i zła i odpowiedniego reagowania na zło. Ważne jest w związku z tym, aby język prawa karnego nie był z tą konwencją sprzeczny. Należy jednak dodać, iż te potoczne pojęcia w żadnym wypadku nie wystarczają do opisu norm prawa karnego, które są liczne i złożone.

Komunikowanie się społeczeństwa na temat norm właściwego postępowania i karania za ich naruszenie odbywa się w sposób prosty i intuicyjny. Komunikacja ta stanowi podstawę języka prawnego, który należy traktować jako szczególny sposób określenia treści norm społecznych. W ten sposób prawo karne niejako nazywa społeczną świadomość i potrzebę w zakresie ochrony stosunków społecznych przy pomocy państwowego karania. W powołanym sensie język prawa karnego jest również językiem jego adresatów.

5. Legitymacja języka prawa karnego związana ze zwierzchnią władzą (a zatem i z językiem) jego adresatów jest wielopłaszczyznowa. Przejawia się ona we wszystkich aspektach języka prawnego, albowiem daje odpowiedzi na takie pytania, jak: czy,

\footnotetext{
${ }^{41}$ Por. W. von Humboldt, O myśli i mowie. Wybór pism z teorii poznania, filozofii dziejów i filozofii języka, Warszawa 2002 (thum. E. Kowalska), s. 261 i nast. oraz s. 494.

${ }^{42}$ Ibidem, s. 453.
} 
dlaczego, kiedy i jak coś jest karygodne lub zawinione? Legitymacja ta ma jednocześnie charakter pozytywny i negatywny. W pierwszym zakresie daje podstawy do wyznaczania norm postępowania (prawa karnego), w drugim zaś - limituje te normy, tak w zakresie ilościowym, jak i jakościowym. Język prawa karnego nie może bowiem nie tylko całkowicie abstrahować od języka jego adresatów, ale również nie może odchodzić od niego stopniu pozwalającym uznać, iż przestaje on być językiem adresatów, czyli staje się przez nich niezrozumiały.

Konieczne przy tym jest zwrócenie uwagi na istotną faktyczną różnicę pomiędzy językiem mówionym a pisanym, jak również pomiędzy językiem potocznym a karnoprawnym. Społeczeństwo komunikuje się zazwyczaj językiem mówionym, nawet jeżeli jest on używany we współczesnych elektronicznych komunikatorach. Tymczasem język prawa karnego, wyrażający ustanowione prawo karne, jest językiem pisanym. Jest to język bardzo specyficzny z co najmniej kilku powodów. Po pierwsze, szczególne są tutaj formuły językowe języka prawa karnego, wynikające $z$ wszelkich determinantów formy przepisu karnego jako jednostki redakcyjnej tekstu prawa karnego (np. zakazów ujmowanych jako typy czynów zabronionych pod groźbą kary kryminalnej, o cym będzie mowa poniżej). Po drugie, szczególna jest również treść wyrażań języka karnoprawnego. Jest to bowiem generalnie rzecz ujmując język zakazów (represji), oparty na założeniu ścisłego i precyzyjnego używania i rozumienia wyrażań zawartych w przepisach prawa karnego. Po trzecie, język karno-prawny jest w istotnym stopniu zdeterminowany tradycją karnistyczna, związaną z używaniem określonych wyrażeń i zwrotów w poprzednich Kodeksach karnych (z 1969 r. i z 1932 r.). Tych wszystkich cech nie posiada potoczny język mówiony, czyli podstawowy język komunikacji społecznej. Wskazana rozbieżność ma charakter trwały i nieusuwalny. Wyrażenia potocznego języka mówionego są bowiem zasadniczo nieadekwatne do opisania norm prawa karnego, który jest językiem specjalistycznym, co wynika z celów i zasad prawa karnego. Przywołana nieusuwalna niekoherentność mowy potocznej z pisanym językiem karnoprawnym stanowi kolejny argument na rzecz uznania, że normy prawa karnego powinny być stosowane $\mathrm{w}$ wyjątkowych przypadkach i tylko odnośnie patologii naruszających dobra społeczne zrozumiałych dla ogółu społeczeństwa.

\section{Język twórców prawa karnego}

1. Język twórców prawa karnego składa się z języka używanego przez twórców przy tworzeniu prawa karnego oraz właściwego języka prawa karnego, tzn. języka prawnego, którego przedmiotem są przepisy karne określające odpowiedzialność karną za przestępstwa. Poniższe rozważania będą dotyczyły tego drugiego języka.

Język prawa karnego twórców jest językiem adresatów w dwojakim znaczeniu. Jest to bowiem jednocześnie język adresatów prawa karnego i język używany przez tychże adresatów, którzy w procesie prawotwórstwa są przedstawicielami adresatów prawa karnego, i w tym sensie - samymi jego adresatami.

Język twórców prawa karnego wyraża cele samego prawa karnego, co czyni go językiem specyficznym. Cel prawa karnego wymaga spełnienia szeregu specyficznych przesłanek pozytywnych i negatywnych, które muszą być uwzględnione w języku prawa 
Robert ZAWŁOCKI, O komunikatywności języka prawnego.

karnego. Okoliczność ta nadaję mu specyficzny charakter, a w szczególności czyni z języka adresatów prawa karnego - język jego twórców. Ten ostatni stanowi zatem wynik swoistego przetworzenia języka adresatów prawa karnego.

Wskazany zabieg przetworzenia powinien sprowadzać się do realizacji wyłącznie i wszystkich warunków koniecznych. Ich treść wynika z celu prawa karnego, a w szczególności - z ich funkcji i zasad. Okoliczności innego rodzaju modelują język prawa karnego bezpodstawnie i dysfunkcjonalnie. Generalną granicą ostateczną legitymizująca przetworzenie jest efekt w postaci języka prawa karnego, który przetwarza język jego adresatów do postaci dla nich niezrozumiałej, a ściślej - postaci, której nie można go wyjaśnić używając języka adresatów.

Jak już stwierdzono powyżej, funkcje i zasady prawa karnego zasadniczo nie tylko mają charakter reguł faktycznych, lecz również często niejednoznacznych (nie rozumianych jednolicie). Oznacza to, iż trudno wyznaczyć charakter i treść właściwych reguł przetwarzających język adresatów prawa karnego w język prawa karnego. Jednakże oczywisty nakaz uwzględnienia tych reguł, wraz $\mathrm{z}$ towarzyszącym mu zakazem uwzględnienia pozostałych, rodzi konieczność powołania przez twórców prawa karnego pełnego merytorycznego uzasadnienia dla każdego aktu tworzenia języka prawa karnego. Uzasadnienie to powinno dawać podstawy umożliwiające zweryfikowanie każdego przepisu karnego w kontekście funkcji i zasad prawa karnego. Brak takiego uzasadnienia sprawia, iż język prawa karnego, choć formalnie oparty na języku jego adresatów, jest sprzeczny $\mathrm{z}$ ich celem, a w szczególności - celem prawa karnego. W takiej sytuacji dochodzi do chaosu komunikacyjnego pomiędzy twórcami a adresatami prawa karnego i dysfunkcji prawa karnego.

W powyższym znaczeniu język twórców prawa karnego jest właściwy, gdy jest uzasadniony. Język prawa karnego i jego uzasadnienie stanowią konieczną i nierozerwalną jedność, w ramach której uzasadnienie określa przesłanki ustanowienia określonej normy prawa karnego, a sama norma stanowi jedynie następstwo tych przesłanek. Przepis karny bez jego uzasadnienia ma taką samą wartość jest uzasadnienie do przepisu karnego, którego brak. Poniżej zostaną opisane elementy konieczne rozważanego uzasadnienia, czyli elementy przetwarzające język adresatów prawa karnego w prawo karne zgodnie z jego istotą.

Z związku z powyższym, należy odnotować, że pod rządami Kodeksu karnego z 1997 r. prawodawca niemal w ogóle nie dba o właściwe uzasadnienie decyzji kryminalizacyjnej, a często tego uzasadnienia po prostu brak, gdy zaś już jest to sprowadza się ono do rozwinięcia treści proponowanych przepisów karnych, a w przypadku rzadko występującego uzasadnienia merytorycznego jest ono chybione. ${ }^{43}$

2. Ogólnymi elementami przetwarzającymi język adresatów prawa karnego w język jego twórców są ogólne reguły prawotwórstwa. Ich normatywna i aksjologiczna podstawa znajduje się przede wszystkim w Konstytucji RP. Jej postanowienia pozwalają sformułować zasadę dobrego prawotwórcy, którą należy traktować szerzej niż postulowaną w nauce zasadę

\footnotetext{
${ }^{43}$ Zob. szerzej: R. Zawłocki, Kodeks karny «śmietnikowy», Tożsamość polskiego prawa karnego, red.: S. Pikulski, M. Romańczuk-Grącka, B. Orłowska-Zielińska, Olsztyn 2011, ss. 76-89.
} 
racjonalnego ustawodawcy. Chodzi bowiem nie tylko o prawotwórstwo poprawne formalnie (rozumne), lecz również właściwe aksjologicznie. ${ }^{44}$

Idea Rzeczpospolitej Polskiej jako demokratycznego państwa prawnego będącego dobrem wspólnym wszystkich obywateli sprawujących w nim władzę zwierzchnią, które urzeczywistnia zasady sprawiedliwości społecznej, wyrażona w art. 1, 2 i 4 Konstytucji RP, pozwala sformułować określone podstawowe wymagania co do stanowienia prawa karnego. Wymagania te należy konsekwentnie traktować jako podstawowe wyznaczniki języka twórców prawa karnego, tzn. kryteria właściwego języka prawa karnego. Należą do nich w szczególności:

(i) celowość prawa karnego (właściwe kryminologiczne i politycznokryminalne uzasadnienie aktu kryminalizacji),

(ii) ostateczność prawa karnego (zasada ultima ratio środków represyjnopenalnych),

(iii) sprawiedliwość prawa karnego (zasada proporcjonalności reakcji karnoprawnej oraz zasada równości wszystkich wobec prawa),

(iv) spójność prawa karnego (stanowienie, interpretowanie i stosowanie prawa karnego w ujęciu systemowym),

(v) stabilność prawa karnego (maksymalne unikanie zmian w obowiązującym prawie i wprowadzania nowych norm karnoprawnych),

(vi) czytelność prawa karnego (stosowanie maksymalnie jasnych i prostych przepisów prawa karnego).

Kolejną ogólną podstawą wyznaczającą warunki właściwego języka prawa karnego są postanowienia art. 42 Konstytucji RP. Zgodnie z ustępem pierwszym tegoż artykułu, źródłem prawa karnego jest wyłącznie ustawa, a w szczególności jej pisemna treść. Język prawa karnego ma zatem formę pisemną. Wymóg ten wynika z przekonania, iż źródła odpowiedzialności karnej w postaci przepisów (norm) prawa karnego powinny być:

(i) ustanawiane w szczególnym trybie, właściwym dla aktów prawnych najwyższej rangi, jaką są ustawy,

(ii) przez organy państwa, w których zasiadają przedstawiciele Narodu,

(iii) o jednej określonej treści dla wszystkich członków społeczeństwa,

(iv) publikowane w sposób ogólnodostępny.

Powołane warunki właściwej legislacji stanowią podstawę do sformułowania m. in. postulatu pisemnej formy języka twórców prawa karnego.

3. Forma pisemna języka prawa karnego stanowi jego konieczny pozytywny warunek. Jednocześnie kreuje ona faktyczną przeszkodę w zabiegu prawidłowego przetwarzania języka adresatów prawa karnego. Jest to naturalne następstwo ograniczeń, jakie niesie za sobą sposób pisemnego komunikowania się w porównaniu z komunikowaniem się ustnym. ${ }^{45}$ Tym bardziej, że w omawianym tutaj zakresie, pierwsze z nich ma dodatkowo

\footnotetext{
${ }^{44}$ Zob. szerzej np. w: H. Izdebski, Elementy teorii i filozofii prawa, Warszawa 2011, s. 284 i nast.

${ }^{45}$ Stanowiace przedmiot badań nauk socjologicznych, interakcje społeczne prowadzą tutaj do wręcz zaskakujących wniosków na niekorzyść komunikacji pisemnej. Jak wskazuje B. Szacka: „Zachowania niewerbalne odgrywają ogromną rolę w komunikacji międzyludzkiej. Obliczono, 
Robert ZAWŁOCKI, O komunikatywności języka prawnego.

charakter pośredni. Ograniczenie pisemnej formy języka prawa karnego realizuje postulat maksymalnego zagwarantowania obywatelom właściwego stosowania prawa karnego, jednocześnie jednak wywołuje inne zagrożenie związane z zakłóceniem komunikacji z tym zakresie. Wydaje się, że pierwsza korzyść przewyższą drugi koszt. Ta pozytywna ocena wskazanego rachunku umacnia się przy uwzględnieniu ewentualnych alternatyw dla powołanego rozwiązania. Naród RP raczej nie zaakceptowałby rozwiązania common law, gdy prawem jest słowna decyzja sędziego. Widoczne wady takiego rozwiązania pokazują doświadczenia krajów takiej kultury prawnej, w których jakkolwiek faktycznym źródłem prawa są zapisane zbiory orzeczeń sądowych, to jednak coraz więcej prawa karnego określa się w generalnych pisemnych aktach prawnych.

4. Komunikacja prawnokarna pomiędzy twórcami a odbiorcami prawa karnego, to komunikacja przy użyciu przepisów ustawy określonego rodzaju. Przepisy prawa karnego materialnego można podzielić na ogólne (określające generalne warunki odpowiedzialności karnej) oraz szczególne (określające dane typy czynów zabronionych pod groźba kary kryminalnej). Przepisy szczególne, co do zasady, składają się z dyspozycji przepisu karnego, w którym prawotwórca określa dany typ zachowania karalnego, oraz sankcje karne, określające zagrożenia karnoprawne za ten typ czynu. Dyspozycja szczególnego przepisu karnego, stanowiącego podstawowe narzędzie języka prawa karnego, określa określony typ czynu zabronionego pod groźbą kary kryminalnej. Prawo karne jest więc formułowane w postaci generalnej matrycy czynu zabronionego. Prawotwórca komunikuje się $\mathrm{z}$ adresatami przepisów karnych wskazując na zachowania karalne. Jest to specyficzny sposób komunikacji. Sprowadza się on bowiem do wskazania, co jest zakazane i jako takie zagrożone karą kryminalną. Perswazja i groźba jest tutaj wyrażona w szczególny pośredni sposób. Przy czym, nie jest to sposób powszechnie stosowany w społeczeństwie, które niepożądane lub naganne zachowania zwykło wyrażać w bezpośredniej prostszej formule zakazu, np. „nie zabijaj”, „nie kradnij”, „nie depcz trawnika” itp. Przywołany sposób komunikacji karnistycznej opiera się na konieczności przeprowadzenia rozumowania według schematu: to jest czyn zabroniony, jeżeli popetnisz taki czyn, to będzie ci wymierzona kara kryminalna. Rozumowanie takie, wbrew pozorom, nie jest proste i wymaga przynajmniej wiedzy o istnieniu zakazu (czynie zabronionym), jak również wiedzy o jego treści, i to przynajmniej takiej wiedzy, która pozwoli adresatowi (sprawcy) sprawnie weryfikować swoje zachowanie z zachowaniem zagrożonym karą kryminalna. Oznacza to, że adresat powinien w pełni uświadamiać sobie językowe znaczenie zakazu karnoprawnego. Efekt taki jest osiagalny jedynie w przypadku prostych zakazów karnoprawnych. Tymczasem prawo kare zasadniczo takich zakazów nie zawiera. Przykładem niech będzie norma

że w toku przeciętnej rozmowy słowa określają charakter danej sytuacji jedynie w 35 procentach, natomiast pozostałe 65 procent wynika z gestów, min, pozycji ciała.” [w:] Wprowadzenie do socjologii, Warszawa 2003, s. 127.

W języku pisanym nie jest również wyrażany niezwykle doniosły element komunikacji językowej, jakim jest akcent, który często decyduje o właściwym znaczeniu (rozumieniu) sformułowania. Por. np. W. von Humboldt, O myśli i mowie. Wybór pism z teorii poznania, filozofii dziejów i filozofii języka, Warszawa 2002 (tłum. E. Kowalska), s. 440-445. 
powszechnie i słusznie uznawana za najprostszą normę prawa karnego, zakazująca zabijania. Przepis art. $148 \S 1$ K. k., brzmi: „Kto zabija człowieka [...]”. Przepis ten, rozpatrywany sam $\mathrm{w}$ sobie, rodzi zasadne np. pytania o każda płaszczyznę tego typu czynu zabronionego: podmiot (czy każdy?), stronę przedmiotową (czy w każdych okolicznościach? czy „zabicie”, tj. wywołanie śmierci, rozumiane jest tutaj potocznie?) oraz stronę podmiotową (czy „świadomie”?). Pytania te są zasadne chociażby z tego względu, iż na każde $z$ nich właściwe są odpowiedzi negatywne. Sytuacja ta nie jest wyjatkowa. Podobny rezultat przynosi zbadanie kolejnej prostej normy, związanej z zakazem „nie kradnij” (zob. art. 278 § 1 K. k.). Warto dodać, że kwestie te komplikuja się jeszcze bardziej przy innych skomplikowanych normach (przepisach karnych). Wynika z tego, że karnoprawny komunikat właściwie z założenia nie jest „komunikatywny” dla przeciętnego obywatela. $Z$ faktu tego należałoby wnioskować, że przepisy karne powinny być traktowane jako skrajnie ostateczna konieczność, stanowiąc środek oddziaływania społecznego na daną patologię społeczną, której w żaden inny sposób nie można zwalczać, a bardzo wysoki koszt ich zwalczania (związany m. in. z ww. „niekomunikatywnością” wpływająca bezpośrednio na ograniczenie praw obywatelskich) nie przewyższa zysków związanych z realnym ograniczeniem tej patologii społecznej.

5. Normy o charakterze karnoprawnym dzielą się na sankcjonowane, czyli zakazujące określonego zachowania pod groźbą kary kryminalnej oraz sankcjonujące, czyli nakazujące określonego postępowania organom stosującym prawo. ${ }^{46}$ Normy te mają zatem dwojakiego rodzaju adresatów: ogółu obywateli oraz osób stosujących prawo karne. Wskazane rozróżnienie nie powinno jednak stanowić podstawy do różnego komunikowania się pomiędzy tymi kręgami podmiotów. Wprost przeciwnie, język norm sankcjonowanych i sankcjonujących powinien być jednakowy.

Przepis karny wyraża zakaz karalnego zachowania się poprzez określenie tegoż zachowania. Prawotwórca określa typ czynu zabronionego poprzez wskazanie jego podstawowych elementów: typu sprawcy, typu karalnego zachowania się, ujmowanego obiektywnie i subiektywnie, zgodnie z założeniem, że na ludzkie zachowanie składają się nierozerwalnie procesy psychiczne człowieka i związana z nimi jego aktywność fizyczna. Należy przy tym podkreślić, że nie ma jakiegokolwiek prawnego wymogu, aby tak właśnie formułować karnoprawny zakaz. ${ }^{47}$ Jest to wynikiem powszechnie przyjętej i historycznie ugruntowanej konwencji, która jest w pełni uzasadniona. Pozwala ona

\footnotetext{
${ }^{46}$ Zob. szerzej w: J. Giezek [w:] M. Bojarski (red.), Prawo karne materialne. Część ogólna i szczególna, Warszawa 2004, s. 56 i nast.

${ }^{47}$ Zasady techniki legislacyjnej dla prawa karnego określają przepisy $\S$ 75-81. Rozporządzenia Prezesa Rady Ministrów z dnia 20.06.2002 r. w sprawie „Zasad techniki prawodawczej” (Dz. U. z 2002 r. Nr 100, poz. 908). Zgodnie z $§ 75$ ust. 1, znamiona typu czynu zabronionego pod groźbą kary kryminalnej powinny być określone w sposób wyczerpujący, bez odsyłania do nakazów i zakazów zawartych $w$ innych przepisach tej samej ustawy. Wyjątkowa możliwość odstapienia od tej zasady legislacyjnej, którą przewiduje ust. 2, zachodzi tylko wtedy, gdy bezprawność czynu zabronionego polega na naruszeniu zakazów lub nakazów wyraźnie sformułowanych w innych przepisach tej ustawy.
} 
Robert ZAWŁOCKI, O komunikatywności języka prawnego.

bowiem udzielić odpowiedzi na następujące pytania: kto popełnił czyn, kiedy, gdzie, jak oraz $\mathrm{w}$ jakich okolicznościach. Niektóre $\mathrm{z}$ tych elementów są wspólne dla wszystkich czynów zabronionych, przez co zostały określone w Części ogólnej KK (np. czas i miejsce popełnienia czynu zabronionego w art. $6 \mathrm{KK}$ oraz wiek sprawcy czynu zabronionego w art. $10 \mathrm{KK}$ ). Dany typ czynu zabronionego zawiera jedynie jego cechy szczególne, które - wraz z ww. cechami ogólnymi - składają się razem na znamiona ustawowe tego czynu. Wyróżnia się w związku z tym następujące elementy (znamiona) typu czynu zabronionego:

1) podmiot (określające cechy sprawcy);

2) strona przedmiotowa (określające cechy karalnego uzewnętrznionego zachowania się sprawcy);

3) strona podmiotowa (określające cechy psychicznego stosunku sprawcy do swojego czynu).

Ad. 1)

Znamię podmiotu czynu zabronionego określa krąg jego możliwych sprawców. Podmiotem czynu zabronionego może być wyłącznie osoba fizyczna zdatna do ponoszenia odpowiedzialności karnej, tj. człowiek w odpowiednim wieku (zob. art. 10 $\mathrm{KK})$. Znamię to najczęściej wyrażane jest przy użyciu zaimka osobowego „kto”, a rzadziej - przy odwołaniu się do konkretnego rodzaju osób (rzeczownika). Z uwagi na podmiot czynu zabronionego wyróżnia się przestępstwa powszechne, zwane też ogólnosprawczymi (delicta communia), tj. przestępstwa, które może popełnić każda osoba, podlegająca odpowiedzialności karnej oraz przestępstwa indywidualne (delicta propria), które moga popełnić tylko konkretnie określone osoby (intraneus), tj. o ustawowo określonych szczególnych kwalifikacjach wyróżniających je od pozostałych osób fizycznych (extraneus).

Ad. 2).

Znamiona strony przedmiotowej to cechy karalnego zachowania się sprawcy, na które składają się znamiona czynności sprawczej, okoliczności czynności sprawczej, przedmiotu czynności sprawczej i skutku czynności sprawczej. Znamiona czynności sprawczej (karalnego zachowania), jako znamiona strony przedmiotowej konieczne w każdym typie czynu zabronionego, określają zewnętrzne zachowanie się podmiotu czynu, a zatem jego istotę. Znamiona te wyrażane są poprzez czasownik użyty w trzeciej osobie w czasie teraźniejszym, dlatego są one niekiedy nazywane znamionami czasownikowymi. Znamiona czasownikowe mogą określać karalny sposób popełnienia czynu zabronionego. Można w tym zakresie wyróżnić sposób określony ogólnie, np. „działa”, „sprowadza”, „powoduje”, albo szczegółowo, np. „zabija”, „niszczy”, „zabiera”. W tym ostatnim przypadku ustawodawca może stypizować jeden konkretny sposób albo wiele alternatywnych sposobów popełnienia czynu zabronionego. W niektórych przypadkach ustawodawca typizuje karalne zachowanie w oparciu o różne sposoby, które dopiero zrealizowane łącznie stanowią czyn zabroniony (tzw. przestępstwa złożone). Dla niektórych formalnych sposobów wystarczające jest faktyczne jednokrotne zachowanie się sprawcy, dla innych zaś - zachowanie wielokrotne (tzw. przestępstwa wieloczynowe). Ze względu na 
sposób realizacji czynności sprawczej (formy czynu) wyróżnia się przestępstwa $\mathrm{z}$ działania i przestępstwa $\mathrm{z}$ zaniechania. Znamiona okoliczności popełnienia czynu zabronionego jako znamiona strony przedmiotowej niekonieczne w każdym typie czynu zabronionego, określają szczególny czas lub miejsce karalnego zachowania się sprawcy albo szczególną sytuację, w której jest ono realizowane. Okoliczności takie nazywane sa również modalnymi, albowiem w specyficzny sposób modeluja one treść i zakres karalnego zachowania się sprawcy (pozostałych znamion strony przedmiotowej czynu zabronionego). Znamiona przedmiotu sprawczego oddziaływania (wykonawczego) jako znamiona strony przedmiotowej niekonieczne w każdym typie czynu zabronionego, określają osoby lub rzeczy, na które skierowane jest zachowanie sprawcy. Jest to w szczególności przedmiot lub osoba, na której jest bezpośrednio wykonywana czynność sprawcza. Należy jednak odróżnić faktyczny przedmiot takiej czynności, który może być praktycznie dowolny, od przedmiotu wskazanego w ustawie. W tym drugim przypadku, posłużenie się innym przedmiotem jest karnoprawnie obojętne. Od przedmiotu wykonawczego należy też odróżnić przedmiot ochrony danego przepisu karnego, tj. dobro prawne chronione tym przepisem. Czasami bowiem zachodzi w tym zakresie faktyczna tożsamość (np. mienie w art. 278 KK). Określenia osób lub rzeczy $\mathrm{w}$ przestępstwach formalnych nie odnoszą się do przedmiotu wykonawczego. Znamiona skutku czynu zabronionego jako znamiona strony przedmiotowej niekonieczne w każdym typie czynu zabronionego, określają zmiany w świecie zewnętrznym, a ściślej w przedmiocie sprawczego oddziaływania. Znamiona skutku mogą być wyrażone pod postacią znamion czynności sprawczej (np. „zabija”) albo odrębnie. Szczególnym rodzajem skutku jest następstwo (zmiana w świecie zewnętrznym nie występujące bezpośrednio po zachowaniu sprawcy jak zwykły skutek), określające tzw. przestępstwa kwalifikowane przez następstwo (zob. art. 9 KK). Przestępstwa znamienne skutkiem określane są jako przestępstwa materialne, a pozbawione tego znamienia - przestępstwa formalne.

\section{Ad. 3)}

Znamiona strony podmiotowej czynu zabronionego wyrażaja naganny (karalny) psychiczny stosunek sprawcy do swojego czynu (faktycznego zachowania). Wskazana cecha czynu zabronionego jest kodeksowo określona na trzy sposoby jako: umyślność (zob. art. $9 \S 1 \mathrm{KK}$ ), nieumyślność (zob. art. $9 \S 2 \mathrm{KK}$ ) oraz tzw. wina mieszana - culpa dolo exorta (zob. art. $9 \S 3 \mathrm{KK}$ ). Na tej podstawie wyróżnia się przestępstwa umyślne i przestępstwa nieumyślne. Przestępstwa nieumyślne ustawa określa wprost (zob. art. 8 in fine KK). Przestępstwa umyślne najczęściej nie zawierają expressis verbis znamion strony podmiotowej, jednak ustawowy opis czynu może zawierać znamiona określające właściwość zamiaru bezpośredniego (np. w celu...). ${ }^{48}$

6. Prawodawca komunikuje się więc językiem prawa karnego sformułowanym w sposób obiektywnie trudny do zrozumienia i stosowania przez przeciętnego obywatela. Omawianą komunikację dodatkowo utrudniają kolejne okoliczności, związane z tym,

${ }^{48}$ Por. R. Zawłocki [w:] Kodeks karny. Część ogólna. Tom I. Komentarz do artykułów 1-31, pod red. M. Królikowskiego i R. Zawłockiego, Warszawa 2011, s. 1101 i nast. 
Robert ZAWŁOCKI, O komunikatywności języka prawnego.

że aktualnie w Polsce obowiązuje ponad sto ustaw zawierających przepisy karne określające przestępstwa $\mathrm{w}$ łącznej liczbie przekraczającej już tysiąc. Połowa tych przestępstw została określona poza Kodeksem karnym, w licznych ustawach szczególnych. Ponadto, znaczna liczba przestępstw charakteryzuje się złożoną konstrukcją i skomplikowaną treścią. Rodzimy ustawodawca dawno już przestał traktować prawo karne jako ultima ratio (środek ostateczny). Obecnie stanowi ono prima ratio ochrony i regulacji stosunków społecznych. Powołane okoliczności bezpośrednio wpływają na złą komunikację prawnokarną pomiędzy państwem a jego obywatelami. ${ }^{49}$

\section{Język interpretatorów prawa karnego}

1. Prawo karne jest interpretowane przez wszystkie podmioty. Najważniejszymi z nich są podmioty stosujące prawo karne oraz przedstawiciele nauki (teorii) prawa karnego. W pierwszym przypadku chodzi o szeroko rozumiane organy wymiaru sprawiedliwości, które opierają swoją interpretację języka prawa karnego przede wszystkim na postulatach teorii prawa karnego. Dlatego w pierwszej kolejności należy omówić zagadnienie naukowego ujmowania języka prawa karnego.

Rodzimą naukę prawa karnego charakteryzuje daleko idąca rozbieżność poglądów praktycznie odnośnie każdego zagadnienia interpretacji karnistycznej. Rozbieżności te zachodzą już na całkowicie fundamentalnej płaszczyźnie odpowiedniego pojmowania istoty przestępstwa, jako podstawy odpowiedzialności karnej. W szczególności można wyróżnić nawet kilkanaście sposobów ujęcia struktury przestępstwa. W tym zakresie odmiennie pojmuje się treści i wzajemne relacje pomiędzy elementami przestępstwa, tj. przesłankami odpowiedzialności karnej. Rozbieżności te bezpośrednio wpływają na odmienny wynik interpretacji karnistycznej niemal w każdej szczegółowej kwestii dotyczącej interpretacji prawa karnego (języka prawno-karnego).

Dodać należy, iż wyżej powołana sytuacja, niewątpliwie dyskomfortowa dla organów wymiaru sprawiedliwości i obywateli, w znacznej mierze spowodowana jest obiektywnym czynnikiem w postaci niejasnych przepisów prawa karnego, czyli niewłaściwie sformułowanego języka prawa karnego.

2. Prawodawca posługuje się językiem prawa karnego w sposób zgeneralizowany. W szczególności, typizuje on zachowania karalne, poddając kryminalizacji określony rodzaj zachowania, uznany za społecznie niebezpieczny w stopniu uzasadniającym wprowadzenie karalności. Ujmuje on dany typ czynu zabronionego w sposób syntetyczny, a nie kazuistyczny. W ten sposób obejmuje ona karalnością wszystkie kazuistyczne przypadki zachowań, które odpowiadają ustawowym cechom (znamionom) typu czynu zabronionego. Rozwiązanie takie pozwala racjonalniej i skuteczniej zwalczać przestępczość, tj. dane społecznie niebezpieczne zachowanie, abstrahując od jego szczególnych specyficznych elementów. Zastosowanie przepisu karnego sprowadza się

${ }^{49}$ Zob. szerzej w: R. Zawłocki, O potrzebie reformy pozakodeksowego prawa karnego, Forum Prawnicze, nr 4/2012, ss. 9-22. 
wtedy w pierwszej kolejności do uznania, że konkretne kazuistyczne zachowanie wykazuje cechy generalnego typu czynu zabronionego pod groźbą kary kryminalnej.

Wobec powyższego, interpretacja karnistyczna może przybrać dwojaki charakter: generalny i kazuistyczny. W pierwszym przypadku interpretacja sprowadza się do szczegółowego wyjaśnienia sensu generalnego typu czynu zabronionego, abstrahujac od konkretnych przypadków (zachowań). Taka interpretacja zasadniczo stosowana jest w komentarzach do ustaw karnych (Kodeksu karnego) i jest domeną teorii (nauki) prawa karnego. W drugim przypadku interpretacja karnistyczna sprowadza się do wyjaśnienia sensu przepisu karnego w odniesieniu do konkretnego zachowania, tzn. do udzielenia odpowiedzi na pytanie, czy dane zachowanie się sprawcy odpowiada znamionom ustawowym określonego typu czynu zabronionego (przestępstwa). Ten rodzaj interpretacji dotyczy podmiotów stosujących prawo. Dodać należy, że właściwie każdy rodzaj ww. wykładni może mieć charakter samodzielny, jednakże są one wzajemnie ściśle powiązane. Interpretacja naukowa w znacznej mierze opiera się na badaniu indywidualnych rozstrzygnięć (orzeczeń sądowych), a interpretacja praktyczna najczęściej czerpie swoje źródło w generalnej interpretacji naukowej.

Tak interpretacja generalna (naukowa), jak i kazuistyczna (praktyczna) opierają się na identycznych zasadach interpretacji karnistycznej, na którą składają się określone rodzaje i reguły takiej wykładni. ${ }^{50}$

3. Wyróżnia się cztery podstawowe rodzaje wykładni karnistycznej: autentyczna, legalną, sądową i naukową. Trzy pierwsze mają charakter wiążący, przy czym wykładnia sądowa ma taki charakter jedynie w zakresie konkretnej sprawy, której dotyczy rozstrzygnięcie. Podstawowym sposobem wykładni przepisu prawnego, a ściślej pojęcia w nim wskazanego, jest definicja legalna tego pojęcia zawarta $\mathrm{w}$ innym przepisie prawnym (wykładnia autentyczna). Przykładem takiej wykładni jest słowniczek definicji legalnych zawartych w art. $115 \S 1-21 \mathrm{~K} . \mathrm{k}$. Wykładnię legalną, którą przeprowadzają upoważnione organy państwa, przewiduje np. ustawa o Trybunale Konstytucyjnym z 1. 08. 1997 r. (Dz. U. z 1997 r. Nr 102, poz. 643 ze zm.). Zgodnie z jej przepisem art. 2 ust. 1 pkt 3, Trybunał orzeka w sprawach zgodności przepisów prawa, wydawanych przez centralne organy państwowe, $\mathrm{z}$ Konstytucją RP, ratyfikowanymi umowami międzynarodowymi i ustawami. Ponadto przepis art. 3 wskazuje, że każdy sąd może przedstawić Trybunałowi pytanie prawne o zgodność aktu normatywnego z Konstytucja $\mathrm{RP}$, ratyfikowanymi umowami międzynarodowymi lub ustawa, jeżeli od odpowiedzi na pytanie prawne zależy rozstrzygnięcie sprawy toczącej się przed sądem. Wykładnię sądową przeprowadza Sąd Najwyższy, który - zgodnie z art. 1 pkt 1 b oraz art. $60 \S 1$ i 2 ustawy o Sądzie Najwyższym (Dz. U. z 2002 r. Nr 240, poz. 205 ze zm.) - jest powołany do podejmowania uchwał rozstrzygających zagadnienia prawa $\mathrm{w}$ celu uniknięcia rozbieżności w wykładni prawa. Ostatnim rodzajem wykładni przepisu karnego jest wykładnia naukowa, która sprowadza się do komentowania w różnej postaci przepisów karnych przez przedstawicieli nauki prawa karnego. Badania naukowe nad prawem

${ }^{50}$ Zob. szerzej w: R. A. Stefański, System Prawa Karnego. Tom 2. Źródła prawa karnego, pod red. T. Bojarskiego, Warszawa 2011, s. 467 i nast. 
Robert ZAWŁOCKI, O komunikatywności języka prawnego.

karnym stanowią więc rodzaj wykładni przepisów (instytucji) prawa karnego i w ten sposób są jednym z elementów jednego tylko etapu interpretacji karnistycznej, jednakże same w sobie nie stanowia jeszcze takiej interpretacji. ${ }^{51}$

Wyróżnia się ponadto reguły wykładni karnistycznej: językową, logiczną, systemową, celowościową i historyczną. Każda z tych reguł ma zastosowanie do każdego z rodzajów wykładni. Podstawowy sposób wykładni przepisu karnego opiera się na regułach językowych. ${ }^{52}$ Jej istota sprowadza się do wyjaśnienia znaczenia pojęć zawartych w przepisie na podstawie ich leksykalnego znaczenia oraz zasady pisowni (np. składni lub interpunkcji), tak w zakresie języka potocznie używanego, jak i języka prawniczego. Należy zauważyć, że choć podstawową funkcją języka jest porozumiewanie się między ludźmi, to jest on również głównym powodem nieporozumień pomiędzy nimi. Chociażby z tego prozaicznego powodu wskazana metoda wykładni często jest niewystarczająca. Warto także podkreślić, że z założenia przepis karny określa czyn zabroniony w sposób ogólny (syntetyczny), albowiem odnosi się do typu zachowań karalnych, a nie do konkretnego zachowania karalnego. Tak więc jest on z natury, w warstwie językowej, wieloznaczny. Wydaje się, że jednoznaczny wynik wykładni językowej jest możliwy tylko w teorii. Nie sposób bowiem racjonalnie argumentować przeciwko zasadzie clara non sunt interpretanda (przepis jasny nie wymaga wyjaśnienia), jednakże z drugiej strony nie sposób również wskazać chociażby jeden przepis w całym systemie obowiązującego prawa, który nie wymagałby pogłębionego objaśnienia. Poza tym trudno nawet w teorii wyobrazić sobie sytuację, w której jednoznaczność językowa (normatywna) przepisu wyłącza całkowicie racje pozostałych metod wykładni. Postulat sięgania do pozostałych reguł wykładni, po niedostatku wyjaśnienia w oparciu o wykładnię językową, należy więc raczej traktować nie jako nakaz interpretacyjny, lecz rezultat poniekąd oczywistego faktu, iż język, w jakim ujęto dany przepis - jako nośnik normy prawnej - jest podstawa wykładni jej treści. W tym znaczeniu pozostałe metody wykładni mają charakter pomocniczy.

Reguła wykładni logicznej korzysta $\mathrm{z}$ formalno-logicznych schematów rozumowania, takich jak np. rozumowanie dedukcyjne (argumentum a maiori ad minus), indukcyjne (argumentum a minore ad maius), czy też - przez przeciwstawienie pojęć (argumentum a contrario).

\footnotetext{
${ }^{51}$ Na płaszczyźnie interpretacji karnistycznej istotne wydaje się tutaj być rozróżnienie na metodę statyczną i dynamiczną wykładni przepisu karnego. Zob. więcej w: R. Zawłocki, O metodzie interpretacji przepisów prawa karnego, Ruch Prawniczy Ekonomiczny i Socjologiczny, 2004 r., z. 4, ss. 81-96.

Kwestią dyskusyjną jest istnienie i zastosowanie ogólnej wykładni prawa, rozumianej jako sytemu generalnych zasad wykładni każdej gałęzi prawa, obowiązującego również na gruncie prawa karnego. Zob. np. M. Zieliński, Wykładnia prawa. Zasady. Reguły. Wskazówki, Warszawa 2002. Wydaje się, że specyfika danej gałęzi prawa determinuje specyfikę i odrębność wykładni jej przepisów.

${ }^{52}$ Na reguły językowe składają się reguły składniowe i semantyczne. Na reguły składniowe składają się reguły formowania (ustalające słownik i gramatyczne) i reguły dedukcyjne (aksjomatyczne i inferencyjne).
} 
Reguła wykładni systemowej pozwala na wyjaśnienie znaczenia przepisu karnego $\mathrm{w}$ powiązaniu z innymi przepisami prawa, zgodnie z założeniem, że należą one do jednego systemu prawnego, a więc są ze sobą spójne i wzajemnie się uzupełniają tak w zakresie treści, jak i funkcji. Tak rozumiana wykładnia systemowa ma charakter formalny. Można jeszcze wyróżnić wykładnię systemową o charakterze merytorycznym, która sprowadza się do systemowej interpretacji karnistycznej opartej o określone koncepcyjne pojmowanie przepisów prawa, a w szczególności przepisów karnych. W zakresie prawa karnego najważniejsze sa tutaj założenia co do ściśle określonego pojmowania struktury przestępstwa (treści i wzajemnej relacji jej poszczególnych elementów), co ma istotny wpływ na określoną interpretację danego przepisu karnego.

Reguła wykładni celowościowej nawiązuje do polityczno-kryminalnych przesłanek i celów wprowadzenia wyjaśnianego przepisu karnego (intencji ustawodawcy). Przyjmuje się wtedy, że treść przepisu wyznaczana jest poprzez jego społeczną funkcję, określona przede wszystkim przez charakter i wagę chronionego dobra.

Metoda interpretacji związana $\mathrm{z}$ reguła wykładni historycznej opiera rekonstrukcję zakresu obowiązywania określonego przepisu karnego na odniesieniu jego treści do przepisów odpowiednich już nie obowiązujących, zgodnie z założeniem ciągłości tego samego systemu prawa. Stosowanie wszystkich wskazanych reguł wykładni opiera się na zasadzie interpretatio cessât in claris (wykładnia kończy się po uzyskaniu jasnego rezultatu).

$\mathrm{Z}$ zasady nullum crimen sine lege (nie ma przestępstwa bez wskazania go w ustawie) i gwarancyjnej funkcji prawa karnego wynika m. in. nakaz ścisłej interpretacji przepisów karnych (nullum crimen sine lege certa - nie ma przestepstwa bez wskazania go w ustawie w sposób ściśle określony). Z nakazu tego należy wywieść swoistą zasadę szczególnego stosowania wszystkich rodzajów i reguł wykładni przepisu karnego, tj. nakazu wykładni zawężającej. Wynikający z niego zakaz rozszerzającej wykładni jest tutaj bezwzględny w odniesieniu do każdej wykładni przepisu karnego, a więc ściśle określa zakres ich stosowania. Żadna $\mathrm{z}$ metod wykładni nie może być stosowana w sposób prowadzacy do rozszerzającego wyznaczenia zakresu zastosowania norm w nim zawartych (z czego wynika m. in. zakaz stosowania w wykładni przepisu karnego reguły logicznej per analogiam).

4. Cechą immanentną języka (prawnego) prawa karnego jest jego wieloznaczność i konsekwentnie towarzysząca jej niejednoznaczność (rozbieżność) interpretacyjna, która w związku z tym również należy uznać za immanentną cechę, a właściwie wynik każdej interpretacji karnistycznej. W tej sytuacji, interpretacja karnistyczna staje się sposobem uzgodnienia sensu języka prawa karnego. Uzgodnienie to faktycznie opiera się w znacznej części na konsensusie intuicyjnym, jednak jego pożądane weryfikowalne podstawy związane są z odpowiednim uzasadnieniem. Treścią tego uzasadnienia są racje (argumenty) odwołujące się do określonych rodzajów i reguł wykładni karnistycznej. Zauważyć jednak należy, że w tym zakresie możliwa jest znaczna dowolność, chociażby z uwagi na brak formalnie ustanowionej hierarchii poszczególnych reguł interpretacyjnych. Nie zmienia to jednak faktu, że interpretacja karnistyczna sprowadza się do uzgodnienia sensu przepisu karnego, w drodze argumentacji karnistycznej, w której 
Robert ZAWŁOCKI, O komunikatywności języka prawnego.

rozstrzygające jest uzasadnienie reprezentujące przekonanie najbardziej racjonalne z punktu widzenia rodzajów i reguł interpretacyjnych. To oznacza, że interpretacja języka prawa karnego musi odwoływać się do niepisanych społecznie przyjętych ogólnych zasad osiagania porozumienia. Naczelną powinna być tutaj zasada interpretacyjna in dubio pro humanitate (w razie watpliwości - na korzyść oskarżonego jako człowieka).

5. Interpretacja karnistyczna, o której była mowa powyżej, dotyczyła przede wszystkim objaśniania przepisu karnego określającego dany typ czynu zabronionego pod groźba kary kryminalnej. Należy w związku z tym wskazać, że odpowiedzialność karna jest konsekwencją popełnienia przestępstwa, tj. czynu zabronionego o określonych cechach przestępnych (bezprawnego, społecznie szkodliwego w stopniu większym niż znikomy i zawinionego).

Pociagnięcie do odpowiedzialności prawnokarnej sprowadza się do przypisania określonej osobie przestępstwa, czyli wszystkich przesłanek odpowiedzialności karnej. Ten zabieg opiera się na swoistej niepisanej konwencji, odwołującej się do stosowania uproszczonych założeń i schematów myślowych. W tym zakresie należy wskazać na dwa najważniejsze zagadnienia. Po pierwsze, jakkolwiek teoretycznie odpowiedzialność karna opiera się łącznie na elementach obiektywnych i subiektywnych, to jednak $\mathrm{w}$ praktyce jest ona stosowana w oparciu o obiektywizację odpowiedzialności karnej. W zabiegu tym pomija się właściwie rzetelną rekonstrukcję okoliczności stanowiących podstawę do stwierdzenia wypełnienia przez sprawcę znamion strony podmiotowej typu czynu zabronionego, jak również zawinienia sprawcy. Po drugie, prawodawca posługuje się przesłankami niejasnymi, co sprawia, że są w znacznym stopniu stosowane są one niejednolicie. Dotyczy to przede wszystkim przesłanki karygodności (wymogu, aby przestępstwo było czynem zabronionym, którego społeczna szkodliwość była wyższa niż znikoma) oraz winy (wymogu, aby sprawcy czynu zabronionego można przypisać winę). Każda $\mathrm{z}$ tych przesłanek nie została zdefiniowana przez prawodawcę.

W powyższym zakresie ogólny i niejednoznaczny język prawa karnego musi być i jest interpretowany odmiennie, co prowadzi do niejednolitej praktyki wymiaru sprawiedliwości. Jednocześnie należy zauważyć, że mowa tutaj o tzw. klauzulach generalnych, tj. konstrukcjach, które z uwagi na swoją złożona naturę opisane są ogólnie, przez co prawodawca celowo powierza organom stosującym prawo odpowiednie ich zastosowanie w indywidualnym przypadku. Stąd można wysnuć wniosek, że język prawa karnego niekiedy nie może być prosty i jasny, tak jak nie jest proste i jasne chociażby pojęcie „sprawiedliwości”, ujmowane jako składnik języka potocznego.

\section{Podsumowanie}

Powyższe rozważania składają się na ,językowe” („komunikacyjne”) rozumienie prawa karnego, przy czym nie jest to ujęcie statyczne, lecz dynamiczne. ${ }^{53}$ Sprowadza się ono do ujmowania prawa karnego jako państwowego i społecznego celowego tworu językowego o określonych cechach. Taka płaszczyzna oceny obecnie obowiązującego

${ }^{53}$ Zob. szerzej np. w: J. Oniszczuk, Filozofia i teoria prawa, Warszawa 2008, s. 790 i nast. 
prawa karnego prowadzi do wniosku, że obecnie, prawodawca w znacznym stopniu i to w sposób bezzasadny, nie ustanawia norm prawnokarnych w sposób w pełni odpowiedzialny, tzn.: świadomy, racjonalny, prosty, zrozumiały i uzasadniony.

Właściwe funkcjonowanie prawa karnego wymaga, aby określano go we właściwym języku. Język prawa karnego musi wykazywać określone cechy, aby był odpowiednim środkiem realizacji celów prawa karnego. Do cech tych należy używanie przez twórców prawa karnego języka adresatów prawa karnego, i to w sposób najbardziej prosty i zrozumiały. Język prawa karnego pozbawiony tych cech nie tylko pozbawia prawo karne skuteczności, lecz dodatkowo wpływa dysfunkcjonalnie na stosunki społeczne, które ma chronić.

Właściwy język prawa karnego stanowi jeden z bezwzględnie koniecznych warunków jego obowiązywania. Jeżeli prawo karne wyrażone jest w niewłaściwym języku, to nie może być podstawą przypisania jego adresatowi odpowiedzialności karnej. Jeżeli bowiem jest ono niezrozumiałe, to nie zostaje mu prawidłowo i skutecznie zakomunikowane, a zatem nie zostaje spełniony fundamentalny warunek funkcjonowania prawa karnego w demokratycznym państwie prawnym. W powołanej sytuacji, z punktu widzenia sprawiedliwości społecznej, obywatelowi nie można zarzucić naruszenia przez niego obowiązku posłuchu dla normy prawa karnego, ponieważ obiektywnie norma ta do obywatela nie mogła dotrzeć z uwagi na istotną wadliwość jej nośnika. Obywatel nie może ponosić odpowiedzialności za to, że państwo ignoruje swoje obowiązki i narusza uprawnienia obywatela.

We współczesnym rodzimym prawie karnym materialnym niemała część przepisów (norm) nie jest określona we właściwym języku prawnym i nie spełnia wyżej rozważanych cech. Dlatego też powinna ona być pilnie usunięta lub poprawiona. $\mathrm{W}$ przeciwnym razie należy się spodziewać, iż zachodzące obecnie w wielu państwach na całym świecie przejawy kontestacji współczesnego porządku społecznego, gospodarczego i politycznego, obejmą również prawo, w tym w pierwszej kolejności prawo karne o charakterze materialnym. Źródło tych wystapień zdaje się być bowiem identyczne, tj. abstrahowanie $\mathrm{w}$ stosowanych rozwiązaniach od rzeczywistych potrzeb i możliwości przeciętnego człowieka. 


\section{Bibliografia}

Cooter, Robert i Ulen Thomas. 2011. Ekonomiczna analiza prawa. Warszawa: Ch Beck.

Giddens, Anthony. 2007. Socjologia. Warszawa: PWN.

Giezek, Jacek 2004. [W:] Prawo karne materialne. Część ogólna i szczególna, red. M. Bojarski. Warszawa.

von Humboldt,Wilhelm. 2002. O myśli i mowie. Wybór pism z teorii poznania, filozofii dziejów i filozofii języka, Warszawa: PWN.

Izdebski, Hubert. 2011, Elementy teorii i filozofii prawa, Warszawa: Lexis Nexis.

Matczak, Marcin. 2007. Summa Iniura. O błędzie formalizmu w stosowaniu prawa. Warszawa: Scholar.

Marek, Andrzej. 2010. System Prawa Karnego. Tom 1. Zagadnienia ogólne. Warszawa: CH Beck.

Marek, Andrzej. 2011. Prawo karne. Warszawa: CH Beck.

Morawski, Lech. 2005. Glówne problemy wspótczesnej filozofii prawa. Prawo w toku przemian. Warszawa: Lexis Nexis.

Nowak, Tomasz. 2011. Jezzyk w świetle nauki. Kraków: Petrus.

Oniszczuk, Jerzy. 2008. Filozofia i teoria prawa. Warszawa: CH Beck.

Stefański, Ryszard, A. 2011. System Prawa Karnego. Tom 2. Źródta prawa karnego. Red, Bojarski tadeus, Warszawa: CH Beck.

Szacka, Barbara. 2003. Wprowadzenie do socjologii. Warszawa: OFICYNA -W"NAUKOWA.

Szerer, M. 1964. Karanie a humanizm. Warszawa: PWN.

Szerer, Mirosław. 1981. Kultura i prawo.Warszawa: PIW.

Sztompka, Piotr. 2005. Socjologia zmian społecznych. Kraków: Znak.

Sztompka, Piotr. 2009. Socjologia. Analiza społeczeństwa. Kraków: Znak.

Wojciechowski, Bartosz. 2009. Interkulturowe prawo karne. Filozoficzne podstawy karania w wielokulturowych spoleczeństwach demokratycznych. Toruń: Wydawnictwo Adam Marszałek.

Wróbel, Wóodzimierz, Zoll, Andrzej. 2010. Polskie prawo karne. Czesśc ogólna. Kraków: Znak.

Zawłocki, Robert. 2004. O metodzie interpretacji przepisów prawa karnego. Ruch Prawniczy Ekonomiczny i Socjologiczny, z. 4.

Zawłocki, Robert. 2007. Pojęcie i funkcje społecznej szkodliwości czynu zabronionego. Warszawa: CH Beck..

Zawłocki, Robert. 2011. Kodeks karny «śmietnikowy», Tożsamość polskiego prawa karnego. W Kodeks karny «śmietnikowy», Tożsamość polskiego prawa karnego red.: S. Pikulski, M. Romańczuk-Grącka， B. Orłowska-Zielińska， Olsztyn: Uniwersytet WarmińskoMazurski.

Zawłocki Robert. 2011. Komentarz do artykułów 1-31. [W:] Kodeks karny. Część ogólna. Tom I. red. M. Królikowski i R. Zawłocki, Warszawa: CH Beck.

Zawłocki Robert. 2012. O potrzebie reformy pozakodeksowego prawa karnego, Forum Prawnicze, nr 4/2012.

Zieliński Maciej. 2002 Wykładnia prawa. Zasady. Reguły. Wskazówki. Warszawa: Lexis Nexis.

Zirk-Sadowski, M. 2011. Wprowadzenie do filozofii prawa. Warszawa: CH Beck. 
